\title{
LAS HERMANDADES Y COFRADÍAS DE LA VERA CRUZ EN EL PAÍS VASCO
}

\author{
POR \\ ERnesto García FernándeZ \\ Universidad del País Vasco \\ Catedrático de Historia Medieval, Facultad de Filología y Geografía e Historia \\ Departamento de Historia Medieval, Moderna y de América
}

\section{RESUMEN}

En este artículo se analiza y valora el período en que se produjeron en el País Vasco las primeras fundaciones de las Hermandades y Cofradías de la Vera Cruz, así como la importancia que tuvo el culto a la Cruz en este territorio. Al mismo tiempo se examinan, de manera más precisa y sistemática, las relaciones manifiestas de la cofradía de la Vera Cruz de Bilbao con la cofradía de la Vera Cruz de Vitoria, cuya fundación está documentada en 1538. De este estudio se deriva que los estatutos de la cofradía de la Vera Cruz de la ciudad de Vitoria fueron tenidos en cuenta por quienes en la villa de Bilbao decidieron instituir dicha cofradía a mediados del siglo XVI.

PAlabRas ClaVE: Religiosidad, cofradías, País Vasco, Hermandades, Vera Cruz, Semana Santa

\section{THE BROTHERHOODS AND FRATERNITIES OF THE TRUE CROSS IN THE BASQUE COUNTRY}

\begin{abstract}
In this paper we analyse the period in which the first foundations of the Brotherhoods and Fraternities of the True Cross took place in the Basque Country and assess the importance that the cult of the Cross had in this region.) In addition, we examine carefully and systematically the evident relations between the fraternity of the True Cross in Bilbao and the fraternity of the True Cross in Vitoria, for whose foundation in 1538 there is documented evidence. This study shows that
\end{abstract}


the statutes of the fraternity of the True Cross in the town of Vitoria were taken into account by those who decided to set up the same fraternity in the town of Bilbao in the middle of the sixteenth century.

KEY WORDS: Religiosity, fraternities, Basque Country, Brotherhoods, True Cross, Easter

Recibido/Received 06-02-2008

Aceptado/Accepted 20-11-2008

\begin{abstract}
«En nombre de Dios omnipotente, Padre e Hijo Espíritu Santo, tres personas y un solo Dios verdadero, en quien tenemos todo nuestro bien y esperanza, arrimándonos al árbol salutífero de la cruz, en que obró nuestro redentor la redención humana, tomándola por nuestro amparo e defensión tanto en el punto de nuestra muerte contra las tentaciones y ocasiones de peligros de este mundo, para los cofrades y hermanos disciplinantes de la Santa Vera Cruz, para que más dignamente seamos por ella amparados, interviniendo la Santísima Virgen María nuestra señora».
\end{abstract}

(Cofradía de la Santa Vera Cruz de Portilla -Álava-, año 1579).

Introducción: el culto a la Cruz y sus manifestaciones en Álava, GUIPÚZCOA Y VIZCAYA

Sin duda, abordar el estudio de las hermandades y cofradías de la Vera Cruz en el País Vasco, así como valorar otro tipo de cuestiones relacionadas con la historia de los cultos y devociones a la Cruz en Álava, Guipúzcoa y Vizcaya, supone un reto para mí en un doble sentido. En primer lugar porque la bibliografía sobre esta temática referente al País Vasco no es abundante y en segundo lugar porque para la Edad Media y la primera mitad del siglo XVI no son muy ricas las informaciones documentales de que disponemos, sobre un culto, el de la cruz, actualmente muy ligado en este y otros territorios a la Semana Santa ${ }^{1}$.

Ciertamente la Cruz en el curso de los siglos se ha ido convirtiendo en un símbolo fundamental de la religión Católica y su utilización ha variado a lo largo de la Edades Media y Moderna. Como una de las representaciones generales principales de los cristianos fue incorporada en las estelas funerarias, en las for-

\footnotetext{
${ }^{1}$ Son conocidas las representaciones o los pasos procesionales celebradas los jueves y viernes Santo en las villas de Bilbao, Valmaseda, Orduña, Durango, Fuenterrabía, Segura, Vitoria, Bermeo, etc., verdaderas «pasiones vivientes» de la conmemoración de la muerte de Cristo. Véase para las tres provincias vascas los trabajos de Julen Zorrozua, Aste Santuko pauso eta irudiak. Pasos e imágenes de Semana Santa en Bizkaia, Bilbao, 2001; Ignacio Cendoya Echaniz, La Semana Santa en Guipúzcoa. Estudio Histórico-Artístico, San Sebastián, 1995; Micaela Portilla Vitoria y José Eguía LóPez de Sabando, Catálogo Monumental. Diócesis de Vitoria. Arciprestazgos de Treviño y Campezo, Vitoria, 1968.
}

Hispania Sacra, LXI

124, julio-diciembre 2009, 447-482, ISSN: 0018-215-X 
mas estructurales de los templos (construcción de las plantas de las iglesias en forma de cruz latina, griega, etc.), en las pilas bautismales ${ }^{2}$, en las capillas de las iglesias ${ }^{3}$, en las medallas, en los ritos parroquiales de carácter procesional ${ }^{4}$, en el último cuerpo de los retablos de las iglesias ${ }^{5}$, en la parte superior de los copones -copón de San Juan Bautista de Quejana, del siglo XIV-, en las custodias -iglesia de Santiago de Salcedo-, en las campanillas para la celebración de los rituales litúrgicos y en los relicarios. Incluso jurar ante la cruz no haber cometido un delito fue considerado como prueba de la inocencia de un presunto delincuente. Así, según el fuero de Tudela, aquellos pastores que juraran ante la Cruz que el ganado desaparecido les había sido arrebatado por una fiera o bestia salvaje debían ser considerados inocentes ${ }^{6}$. Por supuesto, jurar ante la cruz fue un acto que daba relevancia sagrada a lo que se hacía, fuera para presentar pruebas en el seguimiento de un pleito, para reclamar algo ${ }^{7}$ o para acceder a los cargos concejiles, como es el caso de los principales centros urbanos del País Vasco (Vitoria, Bilbao, etc.).

2 Garbiñe Bilbao, Simbolismo e iconografía bautismal en el arte medieval alavés, Vitoria, 1994.

3 Soledad SILVA Y VERÁsTEGUI, Iconografía gótica en Álava, Vitoria, 1987.

${ }^{4}$ El italiano Giovanni Battista Venturino escribía en 1572 lo siguiente sobre la cruz existente en la iglesia colegial de Vitoria: "...Vitoria es capital de Alava, provincia vecina de Guipuzcoa y Vizcaya, aunque con el nombre de esta última se suelen comprender las otras dos. Vitoria es, pues una de las capitales de Vizcaya. Se advierte en ella que las personas del pueblo hablan Vizcaíno o Vascongado, como ellos lo llaman, lengua muy difícil de aprender, si bien los nobles hablan castellano con toda claridad. En la iglesia de Santa María puede verse una gran cruz de plata, excelentemente trabajada, que tiene casi la altura de un hombre; hay en su interior una imagen en madera de nuestra Señora que goza de grandísima devoción...». Véase C. SANTOYO, Viajeros por Álava. Siglos XV a XVIII, Vitoria, 1972.

5 Así por ejemplo en la Rioja Alavesa Cristo crucificado preside o presidía los retablos mayores de las iglesias de Elvillar (1547-1559), Lanciego (segunda mitad del XVI), Elciego (1646-1669), Labraza (1750-1758), de Santa María de los Reyes de Laguardia (1618-1622), Oyón (1624), La Puebla de Labarca (1638-1651), Samaniego (1705-1721) y Moreda (1710-1715). El Cristo de la parroquia de Santa María la Asunción de Elvillar fue bajado de lo más alto del retablo para sacarlo en las procesiones de Semana Santa y nunca más volvió a ser colocado de nuevo en el lugar para el que fue concebido. Hoy en día preside la antigua sacristía, convertida en capilla durante los fríos meses de invierno. La presencia de cruces presidiendo el retablo principal de las iglesias es un fenómeno bastante generalizado en el conjunto las parroquias del País Vasco.

6 Ángel Martín DuQue, «Hacia una edición crítica del Fuero de Tudela», Revista Jurídica de Navarra, 4 (1987), 13-30 - p. 53-.

${ }^{7}$ En 1462 al bachiller Juan Fernández de Cañas, canónigo de la catedral de La Calzada, se le presentan varios testigos alaveses (Pedro Martínez de Mendiola, cura de San Ildefonso, Martín Martínez de Haly, cura de Santa María, Diego Martínez de Salvatierra, clérigo de Vitoria y Juan abad de Avechucho, beneficiado en «Açarrona»), que van a certificar la veracidad de lo que se le solicita, pero antes «les tomo juramento en forma jurídica sobre la cruz e Sanctos evangelios e asy juramentados dixieron que juraban a Dios e a Sancta Maria e a esta señal de la cruz + que corporalmente cada uno dellos toco con su mano derecha e a las palabras de los sanctos evangelios do quiera que estaban de decir verdad...», Archivo Diocesano de Vitoria, caja número 12. 
Cruces procesionales de la diócesis de Vitoria (siglos XIII-XVI) ${ }^{8}$

\begin{tabular}{|c|c|c|}
\hline FECHACIÓN & $\begin{array}{l}\text { LOCALIDAD O LUGAR } \\
\text { DE DEPÓSITO O } \\
\text { PROCEDENCIA }\end{array}$ & IGLESIA PARROQUIAL \\
\hline XIII & IMÍRURI & SAN ROMÁN \\
\hline XIII & MUSEO DIOCESANO & \\
\hline XIII-XIV & SARRÍA & SAN LORENZO \\
\hline XIV & MUSEO DIOCESANO & VITORIA \\
\hline XIV & URABAIN & SAN JUAN BAUTISTA \\
\hline XIV & ESCANZANA & SAN VICENTE MÁRTIR \\
\hline XIV & OYARDO & SAN JUAN BAUTISTA \\
\hline XIV-XV & TREVIÑO & SAN PEDRO \\
\hline XIV-XV & QUEJO & SAN JULIÁN Y SANTA BASILISA \\
\hline XIV-XV & UZQUIANO & NUESTRA SEÑORA DE LA ASUNCIÓN \\
\hline XIV-XV & IMÍRURI & SAN ROMÁN (nudo de cruz procesional) \\
\hline $\mathrm{XV}$ & LUBIANO & NATIVIDAD \\
\hline XV-XVI & UZQUIANO & ASUNCIÓN \\
\hline XV-XVI & BARAMBIO & ASUNCIÓN \\
\hline $\mathrm{XV}-\mathrm{XVI}$ & MUSEO DIOCESANO & CRUZ DE REMATE \\
\hline XV-XVI & BASABE & EL SALVADOR (cruz de pendón) \\
\hline XV-XVI & LLODIO & $\begin{array}{l}\text { SANTUARIO DE NUESTRA SEÑORA } \\
\text { DEL YERMO }\end{array}$ \\
\hline $\begin{array}{l}\text { XV-XVI } \\
(1493-500)\end{array}$ & RIBERA DE VALDEREJO & $\begin{array}{l}\text { CATEDRAL DE SANTA MARÍA DE } \\
\text { VITORIA (cruz de nudos y detalle) }\end{array}$ \\
\hline XVI & ZALDUONDO & SAN SATURNINO DE TOLOSA \\
\hline XVI & URRÚNAGA & SAN JUAN \\
\hline XVI & IMÍRURI & SAN ROMÁN \\
\hline XVI & PORTILLA & SANTÍSIMA TRINIDAD \\
\hline $1520-1526$ & LALASTRA & SANTA ELENA (cruz de nudos) \\
\hline $1526-1528$ & CÁRCAMO & ASUNCIÓN (cruz de nudos) \\
\hline 1557 & DURANA & SAN ESTEBAN (cruz de nudos) \\
\hline
\end{tabular}

8 Véase para Álava y Treviño el monográfico de Rosa MARTín VAQUERo, La platería en la Diócesis de Vitoria (1350-1650). Vitoria, 1997, pp. 91 y siguientes, así como para Guipúzcoa el artículo de S. Cuesta Ezeiza y P. Pérez Zabala «Cruces procesionales góticas en la Diócesis de San Sebastián». Revisión del Arte Medieval en Euskal Herria. Cuadernos de Sección Artes Plásticas y Monumentales, número 15, (1996), pp. 507-514.

Hispania Sacra, LXI

124, julio-diciembre 2009, 447-482, ISSN: 0018-215-X 


\begin{tabular}{|l|l|l|}
\hline FECHACIÓN & $\begin{array}{l}\text { LOCALIDAD O LUGAR } \\
\text { DE DEPÓSITO O } \\
\text { PROCEDENCIA }\end{array}$ & IGLESIA PARROQUIAL \\
\hline XVI & GUINEA & SAN MARTÍN (cruz de nudos) \\
\hline XVI & VILLAMADERNE & SAN MILLÁN (cruz de nudos) \\
\hline XVI & IGAY & SAN ROMÁN (cruz de nudos) \\
\hline XVI & ZÁRATE & SAN PEDRO APÓSTOL (cruz de nudos) \\
\hline XVI & URBINA & SAN ANTOLÍN (cruz de nudos) \\
\hline $\begin{array}{l}\text { XVI (último } \\
\text { tercio) }\end{array}$ & ATIEGA & $\begin{array}{l}\text { SAN FRANCISCO DE VITORIA } \\
\text { (cruz de nudos) }\end{array}$ \\
\hline 1596 & ZURBANO & SAN ESTEBAN (cruz de nudos) \\
\hline $1596-1600$ & CORRO & SAN MIGUEL (Cruz de nudos) \\
\hline XVI & TUESTA & ASUNCIÓN \\
\hline
\end{tabular}

Asimismo en los siglos bajomedievales y modernos fueron frecuentes la edificación de cruceros en la Península Ibérica. Los cruceros, ubicados normalmente en encrucijadas de caminos, están bien documentados en zonas castellanas 9 , navarras ${ }^{10}$, alavesas ${ }^{11}$, vizcaínas ${ }^{12}$ y guipuzcoanas ${ }^{13}$. Es posible que con la implantación de esta simbología se pretendiera por un lado recordar que el pueblo al que se iba a entrar era cristiano, pero asimismo en el imaginario católico la cruz tenía también la función de rechazar y alejar el mal, de modo que dicho símbolo habría de ayudar a combatir los males que pudieran provenir de otros lugares o que pudieran ser traídos por personajes extraños o extranjeros. Desde luego, de esta forma se sacralizaban determinados puntos estratégicos de los caminos y en particular aquellos que se dirigían a los centros de población, aunque en estas representaciones simbólicas se entrecruzaban asimismo significados de carácter penitencial, de propiciación o de acción de gracias. Quiero destacar en este momento los cruceros de Durango -de mediados del siglo XV-y los de Elorrio -el crucero de Santa Ana y el de «Kurutziaga», del siglo XVI-, que tienen una factura artística a destacar, de igual forma que el de Sasamón de Burgos -de fines del XV_14. En Álava sobresalen artísticamente los cruceros de Ali,

\footnotetext{
9 Javier SÁInZ SÁIz, Cruceros de Castilla y León, León, 1993.

10 Véase los números 274, 275, y 276. CRUCEROS, de los Temas de Cultura Popular Navarra, realizados por Fernando Videgáin Agós.

11 Esteban MartíneZ, Cruceros en Álava, Vitoria, 1989.

12 Cosme Barañano y Javier GonZÁlez de Durana, Cruces de Piedra en la provincia de Vizcaya: Iconología del símbolo de la Cruz, Bilbao, 1987.

13 José Zufiaurre GoYa, Cruceros, cruces, picotas y santutxos en Gipuzkoa: (estudio descriptivo de vestigios de religiosidad popular), Donostia, 1995.

14 Véase Salvador ANDRÉS ORdAX, Iconografía cristológica a fines de la Edad Media: El Crucero de Sasamón. Salamanca, 1986 y Valentín de LASuEN, Cruces de término en Bizkaia, Bilbao, 1991.
} 
Armentia, este último bastante deteriorado y Yurre ${ }^{15}$, así como en Guipúzcoa el de Ezkioga.

El crucero de «Kurutziaga» de Durango, antiguamente ubicado en el arrabal de la Cruz, es bien conocido desde el siglo XV. Todavía puede ser contemplado en la actualidad y se ha apuntado que su edificación estuvo relacionada con los herejes de Durango. En este monumento se representa, en uno de los tambores del crucero, la expulsión de Adán y Eva del Paraíso, en el situado inmediatamente en la parte superior de los apóstoles, cada uno con sus respectivos libros como queriendo marcar la importancia de lo que allí se contiene -ellos fueron los responsables de irradiar la doctrina de Cristo, pero a partir del libro sagrado- y finaliza con la escena del Calvario de Cristo que describe la crucifixión del Señor, la cual se levanta sobre una calavera que representa la osamenta de Adán. Lo que viene a significar que Cristo con su muerte en la cruz salva y redime a la humanidad del pecado original cometido por Adán y Eva, así como a todos los hombres y mujeres de la muerte eterna.

En el reverso del Calvario está la Virgen María con el niño y a sus lados las imágenes de Santa Catalina y Santa Bárbara, intercesoras ante Cristo. La Cruz, de grandes proporciones, pues tiene una altura de cuatro metros, se habría edificado como una forma de expiar las culpas de quienes habían participado en la herejía dirigida por el franciscano Alonso de Mella ${ }^{16}$ y estuvo ubicada junto a la ermita de la Soledad de la Vera Cruz, donde se encontraron las imágenes románicas de la Dolorosa y de San Juan. De hecho, en el entorno de la Cruz de Kurutziaga, es decir, a las afueras de la villa, fueron quemados algunos herejes durangueses y la construcción del crucero, según los especialistas en arte, estaría relacionada con este motivo de carácter expiatorio. Esta circunstancia podría explicar la grandeza de este monumento y el contenido iconográfico del crucero: la génesis del pecado del hombre debido a la intervención del demonio en forma de serpiente, los santos apóstoles responsables del contenido de la doctrina cristiana, la liberación de la humanidad gracias a la venida de Cristo a la Tierra y a su muerte y crucifixión por la salvación del hombre.

La complejidad para describir y analizar estas creencias, su significación y su plasmación en la vida cotidiana de las gentes del País Vasco durante la Edad Media y Moderna es evidente. De todas formas, está claro que la Cruz fue una de las devociones más importantes que tuvieron asimismo los vascos, cuyas formas de manifestación histórica son muy diversas. La propia presencia de crucifijos y de esculturas de Cristo en la Cruz en las iglesias parroquiales, en los conventos y en muchas de las ermitas existentes en Alava, Guipúzcoa y Viz-

\footnotetext{
${ }^{15}$ Esteban Martínez, Cruceros en Álava. Vitoria, 1989.

16 Véase Rafael Lamarca Ruiz, Virgilio Bermejo y Elena Angulo, El crucero de Kurutziaga. Pecado y Redención en el Arte Vasco Bajo Medieval. Durango, 1994.
}

Hispania Sacra, LXI

124, julio-diciembre 2009, 447-482, ISSN: 0018-215-X 
caya es una de ellas. Prácticamente en todas las iglesias existen todavía en la actualidad, cruces procesionales. A modo de ejemplo voy a señalar que en el Museo Diocesano de Vitoria se conserva una cruz del siglo XIII, en Lubiano hay otra de la primera mitad del XV y en Nuestra Señora del Yermo (Llodio) otra de principios del XVI, cuya estructura es parecida a otra conservada en Busturia (Vizcaya).

Asimismo en la Edad Moderna se documentan distintos «lignum crucis», entre los que resalto el de Bilbao y el neoclásico de Peñacerrada, de la segunda mitad del siglo XVIII, todo él de plata, en cuyo ostensorio ovalado tiene en el «centro, una cruz para el Lignum Crucis, rodeada de varios huecos para otras reliquias y motivos repujados con los instrumentos de la Pasión» ${ }^{17}$, que debió ser donado por la familia Ramírez de la Piscina. Precisamente la persona que dio origen a este famoso linaje alavés había acudido a Jerusalén para participar en las cruzadas desarrolladas a principios del siglo XII. Otra expresión meridiana de la devoción a la cruz es el número de advocaciones con el nombre de Santa Cruz que se conserva en las ermitas vascas, algunas de las cuales hunden sus raíces en el medievo, mientras que otras son de época Moderna. Así por ejemplo Peña-Santiago en su libro sobre «Las ermitas de Gipuzkoa» recoge nada menos que 57 ermitas con la advocación de Santa Cruz, lo que representa un $7 \%$ de todas las citadas ${ }^{18}$.

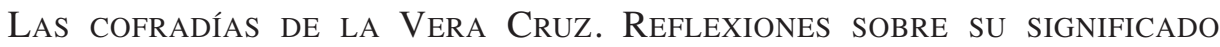
CONFRATERNAL Y SIMBÓLICO

La familia o las vecindades locales fueron una forma de socializar a las personas, es decir, de integrarlas en la vida social. Las redes de amistades se diversificaron a través de la entrada en cofradías, superando de este modo los medios específicos de las familias nucleares -padres e hijos- o los derivados del lugar de residencia -barrio, calle-, así como extendiendo los lazos de relación al crear nuevos vínculos afectivos y en su caso de solidaridad y de ayuda. Por otra parte, al tratarse de asociaciones reconocidas por la iglesia y por los poderes locales, las cofradías fueron convertidas en instituciones básicas de la vida social de una comunidad, de un pueblo o de una ciudad. En casi todos los casos se trata de polos de referencia emotivos que llaman a una identificación entre los que pertenecen a dicha cofradía y a una defensa directa o indirecta de los que allí se

\footnotetext{
${ }^{17}$ Micaela Portilla Vitoria y José Eguía López de SABAndo, Catálogo Monumental. Diócesis de Vitoria. Arciprestazgos de Treviño y Campezo, Vitoria, 1968, pp. 173-174.

${ }^{18}$ L. P. Peña-Santiago, Las ermitas de Guipúzcoa, San Sebastián, 1995. En Heredia, Álava, hubo asimismo una ermita dedicada a la Santa Cruz.
} 
encuentran asociados. Por este motivo en las Edades Media y Moderna fueron con frecuencia organizaciones fundamentales, que favorecieron la integración y combatieron el desarraigo social. Eso sí, todo ello dentro de los cauces de la más estricta ortodoxia cristiana, pues para poder existir legalmente primero debían ser reconocidas y aprobadas por la Iglesia Católica y sus obispados respectivos.

Las cofradías están formadas por grupos más o menos reducidos de personas asociadas en torno a determinados fines y objetivos. La supervivencia de dichas organizaciones necesariamente obliga a sus asociados a reproducir los valores asumidos por las personas que las conforman mediante un fenómeno de relativa endoculturación, es decir, de transmisión de los estilos de vida socio-religiosos de dichos grupos a la generación que le sucede. Por tanto se requiere una enseñanza y un aprendizaje de dichos ideales o prácticas de carácter gregario o social. Esto, por otra parte, es difícilmente realizable si participar en estos grupos no aporta algunas ventajas a la persona, de carácter familiar, social, religioso o algún tipo de reconocimiento privado, semipúblico o público. A su vez en las cofradías con fines fundamentalmente religiosos es muy importante todo un mundo interior de pensamientos y de sentimientos conscientemente individualizados por los miembros de dichos grupos. Existe un código de conductas y de valores religiosos, parareligiosos y de tipo social que es asumido y vivido de distinta forma por cada uno de los cofrades, en función del papel que desempeña en ese mundo asociativo y de la relevancia que se pretende dar a su persona en relación con dicha organización.

Ahora bien el hombre ha organizado sus pensamientos, ideas y actividades religiosas conforme a distintas culturas de carácter ritual. Sin duda, las cofradías religiosas serían desde este punto de vista un culto comunitario, porque sus miembros forman un grupo, que se ocupa y preocupa de poner en práctica determinados postulados y rituales como consecuencia de la tenencia de unas creencias concretas. Estas gentes cuentan de hecho con especialistas religiosos que les asesoran, normalmente clérigos, pero una vez finalizadas sus actividades se retira cada uno de sus miembros a sus actividades cotidianas, es decir, no existe una profesionalización religiosa de los asociados, salvo en los casos en que las cofradías estén formadas exclusivamente por clérigos. Me interesa destacar de las cofradías el hecho de que realicen cultos y ritos de carácter público o semipúblico. Prácticamente la mayoría. No en vano siguiendo las investigaciones más recientes sobre cofradías religiosas, I. Moreno Navarro y Joaquín Rodríguez Mateos han conseguido destacar la importancia de estas tradiciones, reconocidas y valoradas por los poderes locales, desde un punto de vista antropológico «como reflejo de la estructura simbólica de la sociedad», coincidiendo con el cada vez mayor interés del estudio de las fiestas y rituales.

En este sentido «este reflejo de la estructura simbólica de la sociedad» presente en las cofradías ha de estar relacionado con las distintas relaciones de 
fuerza, de poder o de convergencia existentes en la sociedad local. Por este motivo, a lo largo de la historia, es interesante analizar la relación existente entre poder local y cofradías. Las cofradías de la Vera Cruz -bien documentadas en el medievo en otras zonas de la cristiandad europea- ${ }^{19}$, que a lo largo de la Edad Moderna se generalizaron en una parte importante de las localidades del País Vasco fueron una expresión particular de veneración a la pasión de Cristo en la cruz. Cuando un hombre o una mujer se hace cofrade de una cofradía de la Vera Cruz lo ha hecho por motivos personales y cada uno tiene formas diversas de entender y explicar su participación, entrando en juego los sentimientos individuales. Hoy en día la visión y la imagen que se obtiene de las manifestaciones religiosas llevadas a cabo por estas asociaciones varía dependiendo del quién y del cómo se acerquen o aproximen a su estudio: creyentes, ateos, sociólogos, antropólogos, culturólogos, historiadores, etc. Incluso expertos en la materia o personas que, como yo, reflexionan en voz alta desde la historia sobre estos «movimientos religiosos» pueden verse o en su caso sentirse condicionados por la presión y el ambiente social que rodea y enmarca todo lo religioso en un Estado de carácter laico ${ }^{20}$.

En todo caso, en la actualidad -dejando a un lado lo que de subjetividad hay en todo colectivo humano, sea éste o no de carácter religioso-, las cofradías, y más en particular las manifestaciones de carácter público de determinadas organizaciones confraternales, son también un fenómeno cultural y social que supera el marco estricto de lo eclesiástico, religioso o espiritual, para incardinarse asimismo en el mundo del interés de las ciencias sociales. Unas ciencias sociales que tienen al hombre como objeto de sus miradas e investigaciones. El estudio de los patrones sociales y culturales de los hombres organizados en grupos, las respuestas que dan o lo que hacen, sea esto fruto de sus creencias o no, es por tanto interés de las ciencias sociales y culturales. Pues como escribía a fines del XIX, Sir Edwar Burnett Tylor y aceptaba en sus grandes líneas el antropólogo Marvin Harris:

«La cultura...en su sentido etnográfico amplio, es ese todo complejo que comprende conocimientos, creencias, arte, moral, derecho, costumbres y cualesquiera otras capaci-

\footnotetext{
${ }^{19}$ En particular tuvieron un fuerte desarrollo en Italia a partir de la segunda mitad del siglo XIII. Véanse al respecto las Actas del II Congreso Internacional de la Vera Cruz. Caravaca de la Cruz, 2000, Caravaca de la Cruz, 2002. Véase asimismo José SÁnchez Herrero (director), Las cofradías de la Santa Vera Cruz: Actas del I Congreso Internacional de Cofradías de la Santa Vera Cruz, Sevilla, 1995 y específicamente de José SÁnchez Herrero, La Semana Santa de Sevilla, Editorial Sílex. Madrid, 2003.

${ }^{20}$ La presión de la ortodoxia religiosa o de organizaciones fundamentalmente de carácter laicista, el peso de todo un sistema social de valores en torno a esta cuestión, la imposibilidad de cuestionar los valores tradicionales o todo lo contrario, la libertad de denostar unas creencias y rituales son cuestiones con las que se contrae el riesgo de ser considerado un energúmeno por uno u otro tipo de auditorio.
} 
dades y hábitos adquiridos por el hombre en tanto miembro de la sociedad. La condición de la cultura en las diversas sociedades de la humanidad, en la medida en que puede ser investigada según principios generales, constituye un tema apto para el estudio de las leyes del pensamiento y la acción humanos (1871)».

Está fuera de toda duda la atracción que todavía ejercen las cofradías de disciplinantes o las hermandades religiosas en el ambiente cristiano de la Semana Santa -verbigracia la cofradía de la Vera Cruz de San Vicente de la Sonsierra, cuyas ordenanzas datan de 1551-. Esta «llamada popular» puede llegar a generar, en ciertas personas, una relativa fascinación emocional, pero también existen casos contrarios, es decir, de poco aprecio o de un rechazo sistemático de este tipo de cofradías y organizaciones. Por otro lado el hecho de que los días 9, 10 y 11 de octubre de 2004 se celebrara el III Congreso Internacional de Cofradías de la Vera Cruz en Bilbao, a principios del siglo XXI, es efecto del fuerte arraigo que tienen estas asociaciones confraternales en España y en el País Vasco. Desde un punto de vista social y antropológico las cofradías de la Vera Cruz han llegado a ser consideradas como un elemento más que sirve para caracterizar las identidades culturales, sociales y principalmente religiosas de aquellos lugares donde han existido o existen todavía. Igualmente la pervivencia y la continuidad de las cofradías de la Vera Cruz es consecuencia de la capacidad de adaptación de los cofrades y de la cofradía a las distintas realidades históricas y sociales que les ha tocado vivir. Pero las cofradías al manifestarse de forma ritual, siguiendo las ideas de Durkheim, realizan «actos colectivos en los que recrea periódicamente un ser moral del que dependemos todos, la sociedad». La repetición de estos rituales todos los años durante la Semana Santa se convierte de este modo en «un referente ideal que integra, cohesiona, identifica y refuerza al individuo con la sociedad a que pertenece» ${ }^{21}$.

Ahora bien, desde un punto de vista cultural, etnográfico y antropológico, se trata de un ritual ceremonial en el que convergen el imaginario individual, el sentimiento de formar parte de un grupo y la representación pública de carácter semiteatral, cuya ejercitación concreta por los actores, participantes o hermanos comprometidos con estos actos consigue evadirles de la realidad cotidiana y transformarlos en seres que mediante un protagonismo especial y particular, son capaces de lograr una auténtica catarsis y metamorfosis personal. Es indudable que la trascendencia y relevancia de estos rituales es un efecto derivado asimismo del reconocimiento colectivo de estos actos. Actores (cofrades que participan directamente en los ritos) y observadores (cuya participación pasiva no es menos fundamental) constituyen los dos elementos fundamentales de esta ceremonia ritual con un elevado componente de carácter social, además de reli-

21 Joaquín Rodríguez MATEOs, La ciudad recreada. Estructura, Valores y Símbolos de las Hermandades y Cofradías de Sevilla, Diputación de Sevilla, 1998, p. 285.

Hispania Sacra, LXI

124, julio-diciembre 2009, 447-482, ISSN: 0018-215-X 
gioso. El sufrimiento o padecimiento personal de los cofrades en el curso de los eventos eclesiásticos hace trascender todavía mucho más este tipo de actos, revivificando a través del dolor y del recorrido ceremonial a actores y observadores, si bien de distinta manera a cada uno de ellos.

Hechas estas consideraciones creo que es importante destacar, en la historia de las cofradías de la Vera Cruz o de disciplinantes, 3 aspectos fundamentales:

- El papel que desempeñan o han desempeñado como sociedades de hermandad y de integración social.

- Las características de su organización, destinadas a cumplir con los objetivos societarios, además de aquellos otros religiosos y espirituales.

- El desarrollo de una mortificación personal, reflejada en el dolor y sufrimiento físico que algunos de sus miembros soportan estoicamente, buscando en el fondo una catarsis, individual y social, básicamente de carácter religioso y espiritual.

Las cofradías de la Vera Cruz en el País Vasco: los estatutos de las HERMANDADES DE Vitoria y BilbaO

\section{a) Hacia su generalización en el conjunto del País Vasco en el curso de la Edad Moderna}

En el País Vasco, como en otras zonas, desde principios del segundo tercio del siglo XVI, hubo una demanda de fundaciones de cofradías de la Vera Cruz, cuyos cofrades, hombres o mujeres -Portilla, Gordejuela, Navarrete, etc. ${ }^{22}$, tuvieron como referencia central de estas organizaciones a Cristo y como abogado protector a la Virgen María o a San Francisco, como lo expresaban de mane-

\footnotetext{
${ }^{22}$ En Gordejuela las procesiones se organizaban en torno a un crucifijo que debía estar al lado de los clérigos, a continuación iban los cofrades varones con sus belas en las manos, luego un estandarte negro con una cruz colorada, detrás las mujeres con velas en sus manos, rezando o haciendo lo que les hubieran señalado los clérigos. En Portilla las viudas no habrían de ser obligadas a ir a la procesión, ni tampoco debían asistir, ni disciplinarse los hermanos cofrades mayores de 60 años, los enfermos o los ausentes del pueblo. En Navarrete las mujeres que entraran a la cofradía pagaban la mitad que los hombres. En la colegiata de Cenarruza -Ziortza- se implantó en 1612, permitiendo sus estatutos que se pudieran disciplinar indistintamente, hombres y mujeres, aunque esta disposición no fue aprobada por el provisor calagurritano y dos años antes se prohibió la flagelación a las cofradesas de la Vera Cruz de los Santos Juanes de Bilbao, iglesia ubicada en un primer momento en Ibeni-Atxuri-, junto al hospital de los Santos Juanes, si bien tras la expulsión de los jesuitas del colegio de San Andrés de Bilbao en 1767 se desplazó a dicho centro, en la actualidad iglesia de los Santos Juanes. Véase Julen ZorrozuA, Aste Santuko pauso eta irudiak. Pasos e imágenes de Semana Santa en Bizkaia, Bilbao, 2001; Ignacio Cendoya EchanIz, La Semana Santa en Guipúzcoa. Estudio Histórico-Artístico, San Sebastián, 1995, 23-24.
} 
ra clarividente las ordenanzas de la cofradía de la «Santissima»Vera Cruz de la villa alavesa de Navarrete, redactadas a fines del siglo XVI:

\begin{abstract}
«Primeramente tomamos por capitán y guía de esta Santa hermandad y cofradía y de todas las cosas de ella a Jesucristo nuestro Redentor, el cual por su muerte y Pasion venció al enemigo nuestro adversario y nos libró de su servidumbre, porque guerreando siempre debajo debajo de su estandarte y vandera contra nuestros enemigos no perdamos por muchas culpas y flojedad la victoria que el nos alcanzó con su muerte y pasión. Tomamos por Alférez y abogado de nuestra batalla al glorioso San Francisco a quien dio Cristo nuestro capitán la vandera de su milicia imprimiendo en su sagrado cuerpo esteriormente las armas e ynsignias de su victoria y sagrada pasion y nuestra redempcion. $Y$ en todo lo que conviene a la correccion e informacion de las buenas ceremonias y ritos y permanencia de esta Santa Cofradia, desde ahora para siempre, nos ponemos bajo el amparo y defensión de esta Santa Orden, para obligar a los religiosos de ella al favor, amparo y honra de esta Santa Cofradia y todos los cofrades de ella sean obligados a honrar siempre, favorecer y defender a la dicha orden y religiosos de ella como a hermanos y compañeros de nuestra compañía...»²3.
\end{abstract}

Las cofradías de la Vera Cruz se acabaron convirtiendo en las más representativas de la Semana Santa, motivo por el que se llegaron a crear hasta en localidades rurales muy pequeñas, que sin embargo deseaban vivir y sentir una religiosidad penitencial, similar o igual a la de los principales núcleos urbanos. En 1582 los parroquianos de la iglesia de San Juan de Molinar del lugar de Andamendi (Valle de Gordejuela), a través del beneficiado Don Martín de Ibargüen, solicitaron al arcipreste del valle y tierra de Orozco, don Adriano de Isasi, visitador nombrado por el obispado de Calahorra, el permiso correspondiente para instituir una cofradía en honor de la Vera Cruz. La cofradía de la Vera Cruz, como señala Estanislao Labayru, se dotó de ordenanzas, confirmadas y aprobadas por el licenciado Juan Rodríguez de Santa Cruz, vicario general del obispado de Calahorra, señalándose la celebración anual mínima de tres procesiones: "Una el Jueves Santo, otra el día de la Invención de la Santa Cruz, a 3 de Mayo, y la tercera en el día de su Exaltación o sea el 14 de septiembre, 'e otras mas a voluntad de los dichos cofrades ofreciéndose ocasión de peste o guerras o necesidades de agua o de serenidad o de otras cosas', en las cuales saldrían los disciplinantes acompa$\tilde{n}$ ados de todos los cofrades con velas verdes» ${ }^{24}$. Los estatutos de 1589 han sido recogidos en una publicación por Eduardo de Escarzaga 25.

\footnotetext{
${ }^{23}$ Archivo Diocesano de Vitoria. Navarrete, número 14 (1597).

24 Estanislao J. Labayru y Goicoechea, Historia General del Señorío de Bizcaya, Bilbao, 1900, p. 499.

${ }^{25}$ Eduardo de Escarzaga, Descripción histórica del Valle de Gordejuela, Bilbao, 1919, pp. 107109. Las ordenanzas de Santa Vera Cruz de Villaro se hallan en el Archivo Foral de Bizkaia, Libro de Ordenanzas, cofrades, elecciones y cuentas de la Santa Vera Cruz de Villaro (1648-1717), f. 3.
}

Hispania Sacra, LXI

124, julio-diciembre 2009, 447-482, ISSN: 0018-215-X 
Este tipo de cofradías asimismo se extendió por localidades como, Fruniz, Zeanuri, Zalla, Galdames, Villaro (Areatza) - estatutos del siglo XVII-, congregaciones de las que se conservan sus ordenanzas ${ }^{26}$, Cenarruza -estatutos en 1612-, Lequeitio, Ondárroa, Guernica, Ansótegui, Amorebieta -ordenanzas en 1623- y Bermeo, cuyos estatutos se elaboraron bajo el patrocinio de los gobernantes locales en 1550, teniendo su sede hasta mediados del siglo XVIII en la actual capilla de la Pasión del convento de San Francisco, ubicado extramuros de la villa medieval27. En Durango hubo una devoción considerable a la Santa Cruz -en sus términos existió una ermita con dicha advocación, cerca de Abadiano-, y, al menos, desde fines del siglo XVI está documentada la cofradía de la Vera Cruz de Durango ${ }^{28}$. Los cofrades de la Santa Vera Cruz de la villa de Durango disfrutaban por lo menos desde fines del siglo XVI de una ermita propia denominada de la Soledad de la Vera Cruz, ubicada en el arrabal de la Cruz, así llamado porque allí se encontraba la cruz de Gurutziaga ${ }^{29}$.

En el curso de la Edad Moderna un número ingente de poblaciones alavesas, más de cien, dispuso de cofradías en honor de la Vera Cruz, si bien los catálogos del Archivo Diocesano tan sólo documentan la fundación de 15 en el curso de siglo XVI en la diócesis de Vitoria ${ }^{30}$, siendo la más temprana la congregación de la Vera Cruz de la ciudad de Vitoria, cuyos cofrades tuvieron su sede en la iglesia parroquial de San Vicente mártir. En opinión de Fray Juan de Vitoria «...La de la Vera Cruz de San Vicente, que es de los disciplinantes, fundada a instancia del padre fray Tomás de Chaves, dominico de nuestro tiempo, es muy grande, hace solemne procesión el Jueves Santo a la noche y fiesta de la Invención de la Cruz y Exaltación con sermón. Quiso asentar en Santo Domingo y en falta en San Francisco, pero dando los frailes lugar por falta de aparejo, asentaron en San Vicente. San fray Vicente Ferrer, dominico, dio comienzo a esta cofradía en España cerca del año 1400» ${ }^{31}$. De igual modo que en Durango en los términos jurisdiccionales de Santa Cruz de Campezo existió a mediados del

${ }^{26}$ Agradezco la información que al respecto me ofreció en su día María José Lanzagorta Arco.

${ }^{27}$ En 1759 se trasladó su sede a la iglesia de Santa María de la Asunción de la Atalaya, en 1779 a la iglesia juradera de Santa Eufemia y se refundó en la parroquia de Santa María en 1965, dotándose de nuevos reglamentos en 1966. Véase Aingeru Astui ZÁrragA, Semana Santa en Bermeo. 450 años de tradición, Bermeo, 2000, p. 25.

28 Véase F. A. Veitia y R. EcheZARreta, de Noticias históricas de la Muy Noble Villa de Durango, Bilbao, 1967, p. 56 y J. M. Larracoechea BengOA, Notas históricas de la Villa de Durango (I), Durango, 1983 , p. 125.

${ }^{29}$ Información recibida de Jaione Agirre García. Véase asimismo V. ZaVALA, Edad Media de la Villa de Durango, Bilbao, 2001, p. 166.

30 Andagoya, Añastro, Bachicabo, Izarra, Jócano, Nanclares de la Oca, Navarrete, Orbiso, Pariza, Portilla, Subijana Morillas, Viñaspre, Vitoria, Yécora y Vitoria.

31 José Luis Vidaurrázaga e Inchausti, Nobiliario alavés de Fray Juan de Victoria. Siglo XVI, Edit. La Gran Enciclopedia Vasca, Bilbao, 1975, p. 226. 
siglo XVI una ermita con la advocación a la Vera Cruz, donde se establecieron varias beatas, sujetas al convento franciscano de San Julián de Piérola ${ }^{32}$. En la provincia de Guipúzcoa quizá la primera cofradía de devoción a la Santa Vera Cruz se fundó en la villa de Oñate, en 1541, siendo su sede el convento de la Santísima Trinidad de las monjas clarisas ${ }^{33}$.

b) Contexto socio-religioso en el que se funda la cofradía de la Vera Cruz de Bilbao (1554)

La vida religiosa en Bilbao no fue muy distinta de la de otras zonas de la cristiandad medieval, pero sus vecinos y habitantes formaban parte de unos determinados cuadros administrativos eclesiásticos, así como adoptaron unas muy concretas formas de expresar sus sentimientos cristianos, organizándose en torno a instituciones o congregaciones específicamente de clérigos o de laicos. La villa de Bilbao pertenecía a la diócesis de Calahorra, al contrario que la villa Portugalete, dependiente de la jurisdicción eclesiástica del obispado de Burgos.

No obstante, existieron algunas peculiaridades dignas de ser tenidas muy en cuenta, pues no se dieron en ninguna otra zona del mundo cristiano. Me refiero al impedimento que tuvieron los obispos de Calahorra durante la Baja Edad Media para realizar visitas episcopales al Señorío de Vizcaya. De hecho durante los siglos XIV y XV los obispos calagurritanos tuvieron prohibida la entrada en las comarcas del Señorío de Vizcaya que formaban parte de su diócesis ${ }^{34}$. De otro lado, los vizcaínos en el Fuero Viejo de Vizcaya de 1452 llegaron a fijar por escrito las competencias del obispo:

\footnotetext{
32 Véase el Libro de visita del licenciado Martín Gil, Introducción, transcripción y notas de Pablo Díaz Bodegas. Logroño, 1998, p. 270.

${ }^{33}$ Ignacio Cendoya EchanIz, La Semana Santa en Guipúzcoa. Estudio Histórico-Artístico, San Sebastián, 1995 y María José LANZAGORTA ARCO, «La cofradía de la Vera Cruz de Oñate. Un espacio de sociabilidad religioso entre los siglos XIV-XVIII». VII Jornadas de Historia Local. Espacios de Sociabilidad en Euskal Herria, Vasconia, 33 (2003), 441-453.

${ }^{34}$ Ya fines del siglo XIII los arcedianos de Vizcaya tuvieron serias dificultades para ejercer sus funciones eclesiásticas en el Señorío de Vizcaya, uno de ellos llegó a ser asesinado. Y durante los siglos XIV Y XV el título de arcediano de Vizcaya era honorífico, pues no daba derecho a renta alguna en el Señorío de Vizcaya. Véase en relación con las relaciones de Vizcaya con su obispado José ZunZuNEGUI «Las iglesias de Vizcaya y Álava a principios del s. XIII». Idearium, 2, Vitoria (1935), pp. 457482, M․ I. del VAl VAldivieso, «Vizcaya frente al obispo de Calahorra a fines de la Edad Media», Simposio nacional sobre ciudades Episcopales, Tarazona, (1984), pp. 81-90 y J. L. MANERo León, «Relaciones entre la diócesis de Calahorra y el País Vasco a fines de la Edad Media y comienzos de la Moderna según la documentación conservada en el Archivo Catedral Calagurritano», en El Pueblo Vasco en el Renacimiento (1491-1521). Actas del Simposio celebrado en la Universidad de Deusto (San Sebastián) con motivo del $V^{o}$ centenario del nacimiento de Ignacio de Loyola (1-5 Octubre 1990), Bilbao, (1994), pp. 503-522.
}

Hispania Sacra, LXI

124, julio-diciembre 2009, 447-482, ISSN: 0018-215-X 
"Crimen de herejía o sobre recibir absolución de público o sobre rrobo o hurto que fuese fecho en la iglesia sobre violencia de la dicha iglesia o sobre crimen de inzesto que estobiese alguno casado o embarraganado...o sobre tal pleyto que de derecho ni uso ni costumbre pudiesen ni deviesen conocer los juezes seglares o sobre su religion...» (ley primera del título 32 ).

Estas restricciones parecen estar relacionadas con la relevancia que tuvieron en el señorío de Vizcaya las iglesias parroquiales de patronato de los «señores solariegos», que tenían el derecho a presentar los clérigos, a percibir los diezmos y a otras preeminencias varias en los templos durante la celebración de los actos litúrgicos. En la práctica tanto los «señores solariegos» como los gobernantes de las villas vizcaínas con derecho de patronato intervinieron, en contra de lo deseado por las jerarquías eclesiásticas calagurritanas, en cuestiones de índole religiosa, como es visible en los documentos conservados y en las propias ordenanzas municipales de los núcleos urbanos ${ }^{35}$. En otros espacios geográficos de la Península Ibérica para fines de la Edad Media el patronazgo de los nobles y concejos urbanos sobre las iglesias parroquiales fue menos común ${ }^{36}$. Sin embargo pervivieron asimismo iglesias de patronato Real, tanto en el norte como en el sur de la Corona de Castilla, sin que dicha realidad tuviera en ningún caso las consecuencias negativas señaladas en el caso del Señorío de Vizcaya para con el obispo diocesano ${ }^{37}$. Sin duda, para

35 Véase sobre estas cuestiones los trabajos de J. R. DíAZ DE DURANA, «Patronatos, patronos, clérigos y parroquianos. Los derechos de patronazgo sobre monasterios e iglesias como fuente de renta e instrumento de control y dominación de los Parientes Mayores guipuzcoanos (siglos XIV a XVI)», Hispania Sacra, (1998), n 102, vol: 50, páginas 467-508, de E. GARCía FERNÁNDEZ, «Iglesia, religiosidad y sociedad en el País Vasco durante el siglo XIV», Edad Media. Revista de Historia (Universidad de Valladolid), Volumen 8, (2007), pp. 99-144, de Elena CATALÁN MARTÍNEZ, «La pervivencia del derecho patrimonial en la iglesia vasca durante el feudalismo desarrollado», Hispania. Revista Española de Historia, vol. 55, no 190 (1995), pp. 567-587, de Ángel LARREA BEOBIDE, El patronato laico vizcaíno en el Antiguo Régimen, Bilbao, 2000 y de Ernesto GARCÍA FERnÁNDEZ, Gobernar la ciudad en la Edad Media: oligarquías y elites urbanas en el País Vasco, Vitoria, 2004.

${ }^{36}$ Los ejemplos de este proceso de donación, permuta y venta de las iglesias y monasterios por parte de miembros de la nobleza a centros eclesiásticos episcopales o monásticos son bastante numerosos y pueden apreciarse en estudios de carácter regional o en monografías de monásticas. A modo de ejemplo deseo traer a colación cuatro investigaciones: la de José Ángel GARCía DE CORTÁZAR, El dominio del monasterio de San Millán de la Cogolla (siglos X-XIII). Introducción a la historia rural de Castilla altomedieval, Salamanca, 1969, la de Ernesto GARcía FERnÁndEZ, Santa María de Irache: expansion y crisis de un señorío monástico navarro en la Edad Media (958-1537), Bilbao, 1989, la de Luis Javier ForTún PÉREZ DE CIRIZA, Leire, un señorío monástico en Navarra (siglos IX-XIX), Pamplona, 1993 y la de Pablo DíAz Bodegas, La Diócesis de Calahorra y la Calzada en el siglo XIII: la sede, sus obispos e instituciones, Logroño, 2001. En todas ellas se evidencia el fenómeno indicado.

${ }^{37}$ El patronato Real fue considerable en el Reino de Granada, territorio conquistado por los Reyes Católicos en 1492 (Véase J. Suberbiola MartíneZ, Real Patronato de Granada. El arzobispo Talavera, la Iglesia y el Estado moderno (1486-1516). Estudio y documentos, Granada, 1985, Jesús María LÓPEZ ANDRÉs, Real Patronato Eclesiástico y estado Moderno: la iglesia de Almería en época de los 
que aconteciera lo sucedido en Vizcaya, fueron determinantes varias circunstancias: la constitución de Vizcaya en un señorío nobiliario gobernado mayormente por el linaje de los Haro entre comienzos del XI y el año 1379, la asunción en mayor o menor medida por los señores de Vizcaya de una política de distanciamiento o enfrentamiento con el obispo de Calahorra y el «pique de jurisdicción feudal entre el obispo y los señores laicos», en palabras de Tarsicio de Azcona ${ }^{38}$.

Los efectos derivados del veto de entrada al obispo de Calahorra en el Señorío de Vizcaya supusieron una limitación relativa del ejercicio de su poder en la Tierra Llana y en los núcleos urbanos, incluida la villa de Bilbao, aunque particularmente lo centros urbanos no actuaron al margen de las disposiciones emanadas de la sede episcopal calagurritana. Las disposiciones episcopales se intentaron aplicar no tanto a través del arcediano de Vizcaya, cuanto de los arciprestes y de los vicarios de la zona. Hubo intentos desde el siglo XV por eliminar los impedimentos existentes para que el obispo de Calahorra entrara en el Señorío de Vizcaya, caso atípico en otras diócesis, donde los prelados visitaban con distinta regularidad las comarcas que formaban parte de su obispado. Distintas fuerzas sociales y eclesiásticas locales acordaron en vano en 1429, 1445, 1467,1519 romper con esta dinámica antiepiscopal. Pero hasta comienzos del segundo tercio del siglo XVI (1537-1547) ${ }^{39}$ no se consiguió remediar esta situación, siendo obispo de Calahorra el alavés don Bernal Díaz de Luco, cuyos restos se hallan depositados precisamente en la iglesia parroquial de Luco, localidad ubicada entre la villa de Legutiano-Villarreal y la ciudad de VitoriaGazteiz.

Desde el punto de vista de las confraternidades, a fines del siglo XV, sobresalían por su peso social en la villa de Bilbao las cofradías de Santa María, de Santiago -de los mercaderes-, de San Agustín, de San Nicolás -de los zapateros-, de San Miguel y de San Sebastián, hasta el punto de que con sus reivindicaciones intentaban interferir en la vida política municipal. Desde una vertiente estrictamente eclesiástica esta población estaba integrada en el arciprestazgo de Bilbao, que se extendía igualmente por Nuestra Señora de Begoña y San Vicente de Abando.

\footnotetext{
Reyes Católicos, Almería, 1995 y R. MARín LóPeZ, La Iglesia de Granada en el siglo XVI. Documentos para su Historia, Granada, 1996) y todavía eran bastantes las iglesias de patronato Real en Asturias durante el siglo XVII (E. MARTínEZ, «Las iglesias asturianas de patronato Real en el siglo XVII», Boletín del Real Instituto de Estudios Asturianos, año 32, no 95 (1978), pp. 699-713).

38 T. Azcona, «Historia de la Iglesia en el País Vasco. Otoño de la Edad Media: 1378-1516», I Semana de Estudios de Historia Eclesiástica del País Vasco, Vitoria (1981), pp. 69-106 -p. 95-.

${ }^{39}$ T. Azcona, «Historia de la Iglesia en el País Vasco. Otoño de la Edad Media: 1378-1516»... etc., p. 95.
}

Hispania Sacra, LXI

124, julio-diciembre 2009, 447-482, ISSN: 0018-215-X 
En 1488, los clérigos de las parroquias Bilbao (Santiago, San Antonio Abad y Santa María de Begoña) se organizaron en un cabildo dotándose de estatutos que con gran detalle y minuciosidad regulaban gran parte de las actividades, funciones y responsabilidades de los clérigos: el semanero o hebdomadario, el sacristán, el mayordomo, el primiciero y los fieles eran oficios nombrados periódicamente en Año Nuevo, no pudiendo ser desempeñados por la misma persona dos veces seguidas. El acceso a los beneficios eclesiásticos vacantes, según la normativa, era exigente con los candidatos a clérigos de las parroquias de Bilbao, siendo fundamental una buena formación cultural y religiosa, así como ser una persona de buenas costumbres.

En 1503 las iglesias parroquiales del arciprestazgo de Bilbao estaban formadas por 22 clérigos (el arcipreste, curas y presbíteros) y 6 parroquias (Santiago, Santa María de Begoña - del patronato de doña Teresa de Butrón-, San Antón, los Santos Juanes, San Nicolás y San Vicente de Abando), atendiendo aproximadamente a unas 15.000 personas. Al número de 22 clérigos se han de añadir los frailes y monjas de los conventos de San Francisco -a fines del XV- y a principios del XVI el de la Encarnación, compuesto por hermanas dominicas. La fundación de un convento de franciscanos en la villa de Bilbao, a tenor de la influencia que estos frailes tuvieron en el impulso de las cofradías de la Vera Cruz, pudo ser el punto de arranque de la futura cofradía de la Vera Cruz de Bilbao, que se dotó de ordenanzas en 1554, a raíz de las inundaciones que poco antes padeció la localidad. Ahora bien, aunque las ordenanzas de la cofradía se aprobaron por el cabildo eclesiástico el 2 de abril de 1554 en la iglesia de Santiago, tras ser presentadas por los mayordomos y contar con el «acuerdo de los magnificos señores $e$ regimientos desta billa, como patronos de las iglesias della, e ese mesmo con acuerdo e voluntad de los dichos señores de dicho cabildo», fue la iglesia de los Santos Juanes, el centro parroquial en torno al que se configuró la cofradía de la Vera Cruz bilbaína, ya existente, al menos, desde 1553, como reza en el preámbulo de los distintos capítulos del texto conservado:

"Primeramente hordenaron e mandaron que en la santa confradia de la bera cruz de los diçiplinantes e penitentes se çelebrase en la iglesia de los señores San Juanes de esta noble villa de Bilbao y en el altar que esta el santo cruçifico con su Retablo que esta a la parte donde se dize el evangelio y pegado al relicario del santo sacramento. La qual se çelebro e se acordo de lo hazer ansi a catorze dias del mes de setiembre de mill e quinientos e cincuenta e tres años el dia de la exaltazion de la cruz que fue el dilubio en esta villa de Bilbao e acordaron que este presente año fuesen los mayordomos para el serbiçio de la dicha santa confradia de la bera cruz San Juan de Heguia y Francisco de Goiti y Juan de Icaza e Juan de Gamiz vezinos e parrochianos de esta villa de Bilbao e de la iglesia de los señores San Juanes en donde esta ynstituido la dicha santa confradia» ${ }^{40}$.

40 Archivo Municipal de Bilbao, 225/1/3. 


\section{c) Características generales de las cofradías de la Vera Cruz}

Las disposiciones de las ordenanzas conservadas de las cofradías de la Vera Cruz expresan la existencia de una mínima solidaridad y hermandad entre los asociados, al exigir o recomendar la asistencia a los funerales de los cofrades difuntos bajo la amenaza de una serie de penas monetarias ${ }^{41}$, la celebración de misas a favor del alma de la persona fallecida, la solicitud de limosnas para el buen cometido de los actos de la cofradía, la ayuda a los cofrades que hubieran caído en la pobreza o estuvieran muy enfermos y el encargo a los mayordomos de que pusieran acuerdo entre los cofrades enfrentados o que demandaran que tuvieran en su mano una cruz, antes de hablar. Como no podía ser de otra manera existió una estrecha relación de las cofradías con las iglesias parroquiales, centros donde tuvieron su sede, sus propias capillas y oratorios, así como bacines para recoger donativos. Además las procesiones eran presididas, cuando no dirigidas, por los clérigos y beneficiados eclesiásticos de las respectivas parroquias en las que estaba ubicada su sede. Queda claro, por tanto, el necesario consentimiento y reconocimiento de estas cofradías por parte de los clérigos locales, si bien estos pudieron quedar en un segundo un plano en lo que se refiere al proceso de ejecución y puesta en práctica de las mortificaciones disciplinarias el día de Jueves Santo.

En suma, las obligaciones y deberes de los cofrades, recogidas con más o menos precisión en los diferentes capítulos de las ordenanzas, sirvieron para reforzar los lazos de amistad y solidaridad entre los cofrades, con frecuencia ensalzados todavía más mediante actos, ritos y liturgias de carácter religioso. Entre los objetivos de las cofradías de la Vera Cruz se encuentran valores específicos de la ética cristiana, no siendo pequeña su contribución a la concienciación y formación de sus miembros en una determinada moralidad pública. Para ello dispusieron de unos responsables -abades, rectores, prioste y mayordomos- renovados anualmente cada Jueves Santo (Bilbao), así como de una jurisdicción propia, con capacidad para resolver sus pequeñas o grandes diferencias o para penalizar el incumplimiento de las ordenanzas que se habían obligado libremente a cumplir. Por otra parte, ser miembro de una cofradía fue para los clérigos locales y para la Iglesia en su conjunto una forma más de comprometer y responsabilizar a los laicos en un adoctrinamiento cristiano-católico permanente. En este sentido las cofradías de la Vera Cruz fueron verdaderos espéculos para laicos y clérigos, es decir, modelos de referencia religiosa para el resto de la sociedad, en una época especialmente sensible en el credo de la religión Católica -la Semana Santa-, y con un significado fundamental en el cami-

\footnotetext{
${ }^{41}$ En Gordejuela a los cofrades difuntos de la Vera Cruz se les ponía encima del ataúd un paño negro con una cruz colorada en medio.

Hispania Sacra, LXI

124, julio-diciembre 2009, 447-482, ISSN: 0018-215-X
} 
no hacia la salvación de la humanidad, pues Cristo había muerto para salvar a todos los hombres.

En muchas de las localidades donde se fundaron cofradías de la Vera Cruz existieron asimismo otro tipo de cofradías de carácter religioso y era posible ser cofrade de varias de ellas al mismo tiempo. La solidaridad fraternal, en torno a unos objetivos religiosos comunes, en ocasiones, tuvo como consecuencia que entre los cofrades se pudieran acentuar relaciones de amistad, clientelares o económicas. Por consiguiente y de este modo las cofradías, también las de la Vera Cruz, cumplían funciones que iban mucho más allá de las estrictamente religiosas para insertarse en el campo de las realidades económicas y sociales. Ahora bien, las cofradías de disciplinantes sobre todo, al querer sufrir en sus propias carnes algunos de los dolores que Cristo padeció durante el camino que recorrió hasta su crucifixión, pretenden demostrar la necesidad de sufrir y padecer en nombre de Cristo para acercarse y aproximarse a Dios, pues, mediante unos rituales también de carácter ascético, los cofrades con su sufrimiento y su mortificación pretendían conseguir la expiación de sus culpas, según concepción aceptada en distintos ambientes religiosos durante la Edad Media.

Desde luego, el rito «de la sangre», realizado en presencia de una manifestación religiosa popular, sirvió para realzar los lazos de unión entre quienes tomaban parte en estos actos de pasión, para reforzar la identidad del grupo y para fortalecer al conjunto de sus miembros ante el resto de la sociedad. Además el reconocimiento socio-religioso de estos actos por el resto de los componentes de la sociedad laica y eclesiástica refrendaba la propia existencia de su organización y justificaba, con creces, la razón de su ser de carácter mortificador y pasional. Este tipo de ceremonias estaba en todos los casos muy controlada, pero no siempre es conocida la forma en que se llevaba a cabo la procesión. Es interesante en este sentido el capítulo XV de las ordenanzas de la cofradía de la Vera Cruz de Navarrete en Álava (1597), que regula la procesión de Jueves Santo:

«Item ordenamos que para el jueves de la cena estén todos los cofrades hermanos confesados y comulgados, para que la procesión que aquella noche se hiciere sea mas acepta y agradable a nuestro Señor Jesucristo, y haya misericordia y merced de nosotros, y nos perdone todos nuestros pecados, y nos de gracia que en adelante le podamos servir, y no le ofendamos. Y para esto es menester que cada uno muestre cedula del confesor que los ha confesado, porque de otra manera no serán admitidos en la procesión, ni serán tenidos por hermanos ni cofrades de ella. Este dia se hará la misma pesquisa que el día de la Santa Cruz, a cerca de los enemistados, con los cuales se guardará la forma arriba dicha: Este día se hará la procesión de esta manera: A la hora de Tinieblas estarán todos juntos en el lugar para esto señalado y harán colación con mucha honestidad y sin disolución, en memoria de la cena que nuestro Maestro Redentor celebró antes de su sagrada Pasión; la cual acabada se vestirán todos sus havitos blancos de lienzo grosero á manera de cruz con su capilla para cubrirse el rostro y la cabeza, y las espaldas descubiertas y delante un escudo con las cinco llagas, y su cordón de esparto o de cáñamo y una dis- 
ciplina, con todo lo cual irán en la Procesión y vestidos de este modo, el padre, cura o quien dispusieren, les dirá algunos buenos exemplos para animarlos y esforzarlos y ponerlos en algún fervor. Para cuando se acabaren las Tinieblas estarán todos puestos en orden con sus disciplinas en las manos, para cuando los clérigos bajaren y saldrán de la iglesia en esta forma: Primeramente irán delante los clérigos y luego después de ellos un cofrade con una cruz alta donde llevará la imagen de Cristo nuestro redentor y capitán, y después todos los otros uno tras otro (salvo si hubiere tantos cofrades que pareçiere combeniente el que vayan de dos en dos). Y procuren que vayan tantos crucifijos según el número de cofrades, de modo que de veinte en veinte cofrades o de cuarenta en cuarenta si fueren de dos en dos vaya un crucifijo y los que tubieren impedimento para no poder disciplinarse llebarán las insinias de la Pasión y habrá también algunos de los cofrades que guíen la procesión con unas varas berdes con una cruz y un escudo de las cinco llagas en ellas, y harán apartar la gente con mucha cortesía, humildad y silencio para que no se mezclen con los disciplinantes. Hirá también uno, señalado para esto, en la Procesión, en el lugar que les paresciere más combeniente, con una cruz crecida a cuestas y con algunos sayones, a imitación de cómo Cristo nuestro Redentor llevó la Cruz a cuestras al lugar donde havía de ser crucificado, y esto sin disolución ninguna, pues se hace para aprovechar a la gente y a devoción, dolor y memoria de la Pasión de Cristo. Habiendo entrado en la Iglesia los clerigos estarán a una parte y otra, y los disciplinantes en medio y los unos y los otros estarán en pie hasta que el cantor (que para esto fuere señalado) comienza este Vera o cruz ave spes unica y comenzando a cantar el se hinquen todos de rrodillas y entonces y no antes comenzarán los clérigos el Psal. Miserere mei en tono y saldrá la procesión por orden como entraron en la iglesia, e irán los clérigos con ellos en la procesión (para animarlos y esforzarlos) cantando el Psal. Miserere mei en tono y esta procesion irá y solberá por donde el padre cura, abad y mayordomo les pareciere mas combeniente, según la bariedad, disposición o indisposición de los tiempos. Y de ninguna manera permitirán que vaya muger alguna en la Procesión con los disciplinantes disciplinándose. Bueltos a la Yglesia y adorado el Santísimo Sacramento bolberán al lugar de donde salieron y hecho su lavatorio sin ruido ni alvoroto, se irá cada uno con la bendición de Dios. Asimismo los dichos tres días, de la Santa Cruz de Mayo, de la de Setiembre y navidad, los hermanos y cofrades harán una procesión con sus velas y dirán sus misas de la Vera Cruz como ba dicho» ${ }^{42}$.

La conservación de esta penitencia pública a lo largo de los tiempos tuvo mucho que ver con el más allá, es decir, con la búsqueda de la salvación espiritual, así como tiene un profundo sentido simbólico y representativo. El sufrimiento y la ejecución de Jesucristo, lejos de significar la muerte física, representan para los cristianos el triunfo de la vida espiritual y la posibilidad de que todos puedan salvarse gracias a la muerte de uno sólo, de Cristo-Dios, que fue capaz de hacerlo para contribuir a la salvación de toda la humanidad ${ }^{43}$.

\footnotetext{
42 Archivo Diocesano de Vitoria. Navarrete, número 14 (1597). Hay un capítulo muy similar en las ordenanzas de la cofradía de la Vera Cruz de Portilla (1579), cuya transcripción me ha cedido Don Zoilo Calleja.

43 Joaquín Rodríguez Mateos «La devoción a la cruz en la América colonial», Actas del II Congreso Internacional de la Vera Cruz. Caravaca de la Cruz, 2000, Caravaca de la Cruz, 2002, pp. 139150, lo ha expresado de la siguiente manera: «El culto a la cruz en los albores de la Modernidad
}

Hispania Sacra, LXI

124, julio-diciembre 2009, 447-482, ISSN: 0018-215-X 
Son motivos principalmente religiosos los que explican la continuidad de estas cofradías durante la Edad Moderna y la época Contemporánea. No en vano los Papas otorgaron a los cofrades de la Vera Cruz numerosas indulgencias durante el siglo XVI y si siguió el auge fundacional de este tipo de cofradías, en el curso de los siglos XVII al XX, fue sin duda porque aquellas gentes pensaron obtener mayores ventajas espirituales al convertirse en miembros de estas organizaciones religiosas, así como porque, no conviene olvidarlo, durante la Semana Santa esta cofradía tenía un protagonismo social de tal envergadura que para sí lo quisieran muchas otras hermandades. Y la Semana Santa siempre ha sido en el calendario cristiano una de las épocas más importantes del catolicismo.

d) El apoyo del culto a la Cruz por personajes principales de las villas y ciudades vascas: el ejemplo del licenciado Fortún Ibáñez de Aguirre, miembro del Consejo Real y de la Inquisición a principios del siglo XVI

Es difícil, conocer, sin embargo las razones personales que empujaron a los vascos a hacerse miembros de las cofradías de la Vera Cruz o a potenciar este tipo de cofradías en lugar de otras. No me cabe la menor duda, sin embargo, de que los miembros de las cofradías de la Vera Cruz, en cuanto grupo asociativo, sintieron y desarrollaron su vida cotidiana desde su pertenencia a la cofradía, desempeñando un papel muy particular en las comunidades donde residieron, sobre todo el día de la celebración del Jueves Santo en la Semana Santa. Conviene no olvidar que al margen de lo que hubieran pensado en el pasado los propios cofrades de la Vera Cruz, algunos sociólogos, como Salvador Giner, afirman que en la acción social o en la conducta que los cofrades realizaban se encuentra la percepción que los demás hacen de ellos, la interpretación de lo que son, de lo que piensan, de sus valores morales y de sus intenciones o de lo que aparentan ser. La profunda religiosidad vivida por los cofrades de las cofradías de la Vera Cruz, manifestada públicamente a través de sus correspondientes disciplinas y mortificaciones, en recuerdo del padecimiento que sufrió

europea fue acompañado de un ritual ascético dedicado a la contemplación de la Pasión y Muerte de Cristo. La cruz y la sangre, símbolos de muerte y de vida, originaron todo un conjunto de prácticas penitenciales de carácter expiatorio, que supuso un importante elemento catártico para una sociedad religiosamente convulsionada. La búsqueda de una purificación espiritual, dejándose llevar por un fervor religioso necesitado de signos sagrados, vio en la imitación de Cristo una meta laudable, adorándose su cruz redentora al tiempo que se hacían propios sus dolores en una cruenta autolaceración. De este modo, el fenómeno penitencial de la disciplina pública, conocido ya en toda la Europa bajomedieval, resurge fuertemente como ritual expiatorio bajo la tutela de la cruz y la sangre de Cristo, favorecido e impulsado por una iglesia en trance de profundas reformas, principalmente por la acción de la orden franciscana». 
Jesucristo los últimos días de su vida, fue considerada por ellos como vehículos de salvación del hombre, de un hombre acechado en su sociedad por el mal y por el pecado al que querían combatir y del que no siempre tuvieron la fuerza suficiente para evitarlo.

En la ciudad de Vitoria, me llama la atención por su devoción hacia la cruz, el licenciado Fortún Ibáñez de Aguirre, casado con María de Esquíbel. Fue miembro del Consejo Real de la reina Juana «la Loca» y de Carlos V, llegando a presidir coyunturalmente dicho tribunal en 1539. Fue asimismo miembro de la «Santa Inquisición» en tiempos de Juana y de su hijo, el emperador Carlos $\mathrm{V}^{44} \mathrm{y}$ dispuso de rentas y bienes en Medina del Campo, la Isla de Gran Canaria, Sevilla, Utrera, etc. Fue uno de los 20 miembros del Consejo Real considerados por los comuneros como ejemplo de la corrupción y el mal gobierno. Más aún el propio Cisneros expulsó a Fortún Ibáñez del Consejo, tras haber sido acusado de malversar fondos de la Inquisición, si bien posteriormente fue readmitido por Chièvres ${ }^{45}$. Este personaje financió la iglesia del Convento de dominicas de la Santa Cruz de Vitoria, donde se encontraba «soror Ana del Licenciado Aguirre», que según Juan Vidal-Abarca podría ser hija natural de Fortún. Fortún Ibáñez de Aguirre, llegó a fundar en la parroquia de San Vicente mártir de Vitoria la capilla de la Cruz -en la actualidad de la Milagrosa- donde se encuentra un gran escudo de armas del emperador Carlos V en la parte superior y en la inferior los escudos de armas de los componentes de la familia, a la izquierda (Galarza-Aguirre) y a la derecha (Colodro-Esquíbel). En esta capilla fueron enterrados su mujer y él, ella en 1536 y él en $1548^{46}$. Los cofrades de la Vera Cruz celebraron honras en su favor, lo que denota, casi con toda seguridad, la pertenencia de Fortún Ibáñez a la cofradía.

Pero me interesa destacar de manera particular -además del apoyo que ofreció al convento femenino dominico de Santa Cruz, así como a la construcción de su iglesia ${ }^{47}$, la devoción que tuvo hacia la cofradía de la Vera Cruz, orde-

${ }^{44}$ El licenciado Fortún Ibáñez de Aguirre fue consejero de la Inquisición en 1509 y otro vasco, Martín de Azpeitia, lo había sido en 1502, y llegó a ser presidente del Consejo de Aragón en 1506. Véase José Martínez Millán, «Las elites de poder durante el reinado de Carlos V a través de los miembros del Consejo de Inquisición (1516-1558)», Hispania, XLVIII, 168 (1988), 103-167.

45 Véase Joseph Pérez, La revolución de las Comunidades de Castilla (1520-1521), Madrid, 1979, pp. 187-188.

46 Véase al respecto Juan Vidal-Abarca, «Linajes Alaveses. Los Aguirre: Marqueses de Montehermoso», Boletín de la Institución Sancho el Sabio, Vitoria (1975), pp. 183-253 y del mismo autor «Testamento y Mayorazgo del Licenciado Fortún Ibáñez de Aguirre», Boletín de la Institución Sancho el Sabio, Vitoria (1976), pp. 391-414. Ana del Licenciado Aguirre fue una de las monjas dominicas que asistió al acto de consagración de la iglesia del convento de Santa Cruz el año 1522.

${ }^{47}$ En la villa de Bilbao existió otro convento femenino con la advocación de Santa Cruz o de Santa Isabel, pero en este caso se trató de beatas franciscanas, ubicado en un primer momento en Zaballa -Zabalbide- y posteriormente en Ascao.

Hispania Sacra, LXI

124, julio-diciembre 2009, 447-482, ISSN: 0018-215-X 
nando construir una capilla en la iglesia de San Vicente mártir con dicha advocación y previendo en su testamento que en caso de que no se pudiera transmitir el mayorazgo por falta de heredero se construyera un hospital de la Santa Cruz en los palacios que tenía en la Villa de Suso, es decir, en el lugar donde ahora se encuentra el palacio de Montehermoso. Es la primera vez que he encontrado en los testamentos del País Vasco el testimonio de ordenarse la construcción de un hospital de la Vera Cruz, aunque no dejó de ser una manda que nunca se llegó a poner en práctica, pues exigía previamente carecer de descendencia directa. El testamento, redactado en 1535, fue muy explícito sobre este asunto, lo que evidencia la intensa devoción que este personaje destacado de la elite y oligarquía vitoriana tuvo a la Vera Cruz:

\begin{abstract}
«Primeramente queremos y mandamos que en la dicha nra casa principal con su huerta e corral se haga un hospital que se llame de la Vera Cruz e para ello se aderecen las dichas casas y se hagan en ellas los aposientos necesarios para las personas que en ellos han de estar y queremos que en dicho hospital se acojan ocho pobres varones y ocho mugeres que sean personas hijosdalgo e vecinos de la dicha ciudad, si los hubiere, e sino hubiere tantos hombres e mugeres hijosdalgo, que sean labradores o labradoras e que sean vecinos e vecinas de la dicha ciudad de Vitoria, e si no los hubiere de la dicha ciudad, que sean las personas que faltaren de los lugares de la jurisdicción de la dicha Ciudad o del lugar de Elburgo e su jurisdicción, pero si hubiere personas de nuestro linaxe, hombres o mugeres, o del linaxe de los que hubieren tenido e poseido los dichos bienes, que estos tales sean preferidos a todos los otros. Mandamos que les den de comer e beber y vestir tanto quanto bastare la renta que dexaremos en la dicha casa y que los dichos pobres estando buenos vayan a oir misa a la iglesia del señor San Vicente, e que se puedan enterrar en la dicha capilla si quisieren pero si alguno o alguna de los dichos pobres estuvieren malos, que los capellanes de la capilla les digan misa en el dicho hospital todos los días que estuvieren malos, aunque las dexen de decir en la dicha capilla; $y$ para esto mandamos que en el dicho hospital se haga una capilla donde se puedan decir las dichas misas y que la dicha capilla se sirva de todos los ornamentos y otras cosas necesarias que dexamos en la dicha capilla del señor San Vicente»48.
\end{abstract}

Incluso se especifica que los patronos, responsables de la gobernación del hospital y de la capilla de la Cruz de la parroquia de San Vicente mártir de Vitoria, pertenecieran a su mismo linaje o al de su mujer, los cuales juntamente con el alcalde de Vitoria, serían los encargados de elegir a las personas que habrían de ingresar en el hospital, dándose preferencia a los del linaje o parientes de los patronos, pero abriendo igualmente la puerta a cualquier otro individuo necesitado ${ }^{49}$.

\footnotetext{
48 Véase Juan VidAL-ABARCA, «Testamento y Mayorazgo del Licenciado Fortún Ibáñez de Aguirre», Boletín de la Institución Sancho el Sabio, Vitoria (1976), pp. 391-414 -p. 401-.

49 «Y dexamos por patrones del dicho hospital y capilla a los dos parientes mas propincuos del linaxe de mi el dicho Licenciado e de mi la dicha doña María, que el uno de ellos sea del linaje de mi el dicho Licenciado y el otro de mi la dicha doña María que sean buenas personas, y al allde de la ciudad de Vitoria, los cuales elijan las personas que han de estar en el dicho hospital con que como dicho es
} 


\section{e) La influencia del modelo de ordenanzas de la cofradía de la Vera Cruz de Vi- toria en los estatutos de la cofradía de la Vera Cruz de Bilbao}

El análisis de las ordenanzas de las cofradías de la Vera Cruz de Vitoria ${ }^{50}$ y de Bilbao ${ }^{51}$ evidencia que en los estatutos de la villa de Bilbao hay varios capítulos concomitantes en los que se aprecia una relativa literalidad y seguimiento de las ordenanzas vitorianas, del mismo modo que sucedió en otras cofradías alavesas -la de Portilla-.

habiendo pariente o parienta de nro linaje sea preferido a los otros, y después, si hubiere algún pariente o parienta de los dichos patrones, que la tal persona sea preferida a otros e así mismo hagan y manden hacer todas las otras cosas necesarias a la buena administración del dicho hospital e al buen tratamiento de las personas que en él han de estar, proveyendolos de médicos y medicinas y todas las otras cosas necesarias; e damos le poder y facultad para poder hacer todas las ordenanzas que vieren que son necesarias para la buena gobernación de los pobres y la buena administración de la hacienda del dicho hospital y conservación de la dicha casa hospital; y así mismo los dexamos por patrones de la dicha nra capilla de San Vicente y queremos que elijan las personas que han de estar en el dicho hospital, personas que verdaderamente tengan necesidad, e así mismo buenas personas para capellanes dla dicha capilla guardando las constituciones y ordenanzas por nosotros hechas e pedimosles por merced que por servicio de Dios tengan especial quidado de la buena administración del dicho hospital y capilla; e queremos y mandamos que de los dichos nros bienes que así dexamos al dicho hospital les den por el dicho cargo cada tres ducados de oro cada un año a cada uno de los susodichos patronos y aunque merescían mucho más lo demás que lo hagan por servicio de Dios.

Otrosí queremos y mandamos que el que últimamente poseyere los, dichos bienes goce de los dichos bienes por sus días con tal que no se case segunda vez y que pueda hacer las ordenanzas que viere que convienen para la administración del dicho hospital y nombrar las personas que después de sus días y de los días de su muger han de quedar en el dicho hospital». Véase Juan VIDAL-ABARCA, «Testamento y Mayorazgo del Licenciado Fortún Ibáñez de Aguirre», Boletín de la Institución Sancho el Sabio, Vitoria (1976), pp. 391-414 -p. 402-.

50 Véase María Josefa SANz Fuentes, «Dos cofradías de la vera Cruz en tierras de Álava: Vitoria y Tuesta. Sus reglas», en José SÁnchez Herrero, Las cofradías de la Santa Vera Cruz: Actas del I Congreso Internacional de Cofradías de la Santa Vera Cruz, Sevilla, 1995, pp. 755-760; Iñaki BAZÁn DíAZ y María Ángeles MARTín Miguel, «Aproximación al fenómeno socio-religioso en Vitoria durante el siglo XVI: la cofradía de los disciplinantes de la Vera Cruz», Espacio, Tiempo y forma. Revista de la Facultad de Geografía e historia. Separata, Historia Moderna, Madrid, (1993), 231-250. En La Rioja las dos primeras cofradías de la Vera Cruz con estatutos se documentan en Nájera (1533) y en Logroño (1537), en este último caso con una clara influencia del convento franciscano existente en dicha ciudad. En 1551 se aprobaron las ordenanzas de la cofradía de la Vera Cruz de San Vicente de la Sonsierra. (Fermín LABARGa GARCíA, «La devoción a las Cinco Llagas y a la Sangre de Cristo en las cofradías riojanas de la Vera Cruz», en Religión y Símbolos. 18, Zainak. Cuadernos de Antropología-Etnografía, Iruña, (1998), 381-392.

${ }^{51}$ Véase a este respecto el espléndido libro de María José LanZagorta Arco, Cofradía de la Santa y Devota Vera Cruz de Bilbao. 450 años de huella profunda en la villa. 1554-2004, Bilbao, 2004.

Hispania Sacra, LXI

124, julio-diciembre 2009, 447-482, ISSN: 0018-215-X 


\section{Capítulos similares en las cofradías de la Santa Vera Cruz de Vitoria (1538) y de Bilbao (1554)}

\begin{tabular}{|c|c|}
\hline VITORIA & BILBAO \\
\hline $\begin{array}{l}\text { DEL DOMINGO DE RAMOS. } \\
\text { Ordenamos que todos los hermanos con- } \\
\text { frades sean congregados juntos el domingo } \\
\text { de rramos despues de medio dia siendo lla- } \\
\text { mados por nuestro munidor en nuestro orato- } \\
\text { rio y ay sean exortados e rrogados se confies- } \\
\text { sen y comulguen dentro del jueves sancto } \\
\text { de la çena e traxa cada uno dellos el jueves } \\
\text { Sancto su çedula de como es confesado o } \\
\text { haga una solemnidad de como es confesa- } \\
\text { do porque consiga y gane la indulgencia } \\
\text { plenaria conçedida de los Summos Pontifi- } \\
\text { ces a los hermanos de esta confradia e asi- } \\
\text { mismo sean prevenidos vengan el jueves } \\
\text { de la çena del señor con sus aparexos de tu- } \\
\text { nica y de disciplinas a ora limitada por las } \\
\text { hermanos presentes so pena de una libra de } \\
\text { çera cada uno que no se confessare o hiziere } \\
\text { la dicha solenidad. }\end{array}$ & $\begin{array}{l}\text { Yten hordenamos que en el domingo de } \\
\text { rramos por pregon sean llamados después } \\
\text { de comer todos los confrades y penitentes de } \\
\text { la dicha confradia a la yglesia de los señores } \\
\text { sanjuanes y ende sean hesortados e rrogados } \\
\text { por los dichos mayordomos se confiesen e se } \\
\text { comulgen dentro del juebes santo de la } \\
\text { çena e cada uno dellos traiga su çedula de } \\
\text { confesion para el juebes de la çena para } \\
\text { que ganen la indulgencia plenaria conçedi- } \\
\text { da por los sumos pontífices a los confrades } \\
\text { de la dicha santa confradia e sean prebeni- } \\
\text { dos e bengan el juebes de la çena del señor } \\
\text { con sus aparejos de tunica e disciplinas a } \\
\text { la ora limitada que por los dichos mayor- } \\
\text { domos les fuera echo saber sopena de una li- } \\
\text { bra de çera cada uno que no se confesare o no } \\
\text { hiziere la dicha solenidad. }\end{array}$ \\
\hline $\begin{array}{l}\text { DEL JUEVES SANCTO. } \\
\text { Ordenamos que el jueves Sancto de la } \\
\text { cena a la ora situada vamos todos a la di- } \\
\text { cha yglesia dentro de nuestra oratoria con } \\
\text { nuestros avitos o velatorios y antes / que } \\
\text { salgamos con nuestra procesion oyamos } \\
\text { una predicaçion breve de un religioso } \\
\text { competente a nuestro Rector e mayordomos } \\
\text { con que no sean de dos rreales y el confrade } \\
\text { que faltare paque de pena tres libras de çera. } \\
\text { DE JUEVES SANCTO. } \\
\text { Ordenamos que en la noche de jueves } \\
\text { Sancto o otro dia de / congregaçion de los } \\
\text { hermanos si por caso alguno mal mirando } \\
\text { el serviçio de Dios y no veniendo con el } \\
\text { acatamiento devido pusiere algun escan- } \\
\text { dalo o rruido o se desmandare de palabra } \\
\text { o de obra contra otro alguno pague de } \\
\text { pena dos libras de çera. }\end{array}$ & $\begin{array}{l}\text { Yten hordenamos que el juebes santo } \\
\text { de la çena a la hora situada bayan todos } \\
\text { los dichos confrades e penitentes a la yglesia } \\
\text { de los dichos sanjuanes con sus abitos o bis- } \\
\text { tuarios e antes que salgan con su proçesion } \\
\text { oyan una predicaçion brebe de un religio- } \\
\text { so competente para probocar la deboçion de } \\
\text { la santa bera cruz y se de al dicho predicador } \\
\text { por los dichos mayordomos el salario acos- } \\
\text { tunbrado y el confrade que faltare de venir al } \\
\text { dicho sermon pague dos libras de çera e para } \\
\text { ello los dichos mayordomos se an obligado } \\
\text { de hazer pregona para que todos parezcan } \\
\text { como esta dicho de susu. } \\
\text { Yten hordenaron que en la noche del jue- } \\
\text { bes santo e otro dia de congregación de los } \\
\text { dichos confrades si alguno mal mirando el } \\
\text { serbiçio de Dios nuestro señor e no beniendo } \\
\text { con el acatamiento debido pusiere algun es- } \\
\text { candalo o rruido e se desmandare de pala- } \\
\text { bra o de obra contra otro alguno pague de } \\
\text { pena dos libras de çera e luego le executen } \\
\text { los dichos mayordomos para los gastos nece- }\end{array}$ \\
\hline
\end{tabular}




\begin{tabular}{|c|c|}
\hline & $\begin{array}{l}\text { sarios de la dicha confradia e los dichos ma- } \\
\text { yordomos sean obligados de executar sola di- } \\
\text { cha pena e la justicia seglar proçeda contra los } \\
\text { delinquentes con firmeça e derecho. }\end{array}$ \\
\hline $\begin{array}{l}\text { DE LOS ESTRANJEROS. } \\
\text { Otrossi ordenamos que si por casso al- } \\
\text { guna persona con devoçion se encomenda- } \\
\text { re a la ora de su muerte a la dicha hermani- } \\
\text { dad y rogase la resçivan por confrade sea } \\
\text { rreçivido por confrade y le llieven toda la } \\
\text { çera e vamos todos a la sepultura so la pena } \\
\text { arriva dicha e se le diga su missa de rre- } \\
\text { quien e rresponso con que de e pague un cas- } \\
\text { tellano de oro para las costas de la missa e } \\
\text { cera que en sus obsequias se gastaren y si } \\
\text { fuere pobre vamos todos con las quatro achas } \\
\text { solamente a lo sepultar. }\end{array}$ & $\begin{array}{l}\text { Yten hordenamos que si alguna perso- } \\
\text { na con deboçion se encomendare en la san- } \\
\text { ta confradia de la Bera Cruz a la hora de su } \\
\text { muerte rrogandolo reçiban por confrade } \\
\text { sea rreçibido e le lleben toda la çera acos- } \\
\text { tunbrada e le bayan todos a honrrar so la } \\
\text { pena dicha arriba e se diga su misa segui- } \\
\text { damente como arriba se contiene con que de } \\
\text { e pague para las costas de la misa e çera e } \\
\text { esequias que gastare quinientos maravedis e } \\
\text { si fuera probe bayan todos como dicho es } \\
\text { arriba a lo sepultar sin que pague nada. }\end{array}$ \\
\hline $\begin{array}{l}\text { DEL RRESÇIVIR CONFRADES. } \\
\text { Ordenamos que nuestro Rector e ma- } \\
\text { yordomos no resçivan en esta nuestra her- } \\
\text { manidad ningun confrade sin lo hazer sa- } \\
\text { ver a todos los hermanos porque primero } \\
\text { sepan del tal que ha de ser resçivido si } \\
\text { condesçendera con la obra e voluntad y } \\
\text { condiçion en todo aquesto que se contiene } \\
\text { en estas / nuestras ordenanças y que el tal } \\
\text { asi rrescivido pague de entrada tres rreales } \\
\text { y si es hijo de confrade Real y medio. }\end{array}$ & $\begin{array}{l}\text { Yten hordenamos que en la dicha con- } \\
\text { fradia no fuere rreçibido ningun cofrade } \\
\text { sin sabiduria de todos los quatro mayordo- } \\
\text { mos para que sepan el que ha de ser rreçe- } \\
\text { bido con que condiciones e boluntad y } \\
\text { obra se ha de entrar en la icha confradia e } \\
\text { le hagan saber lo contenido en estas horde- } \\
\text { nanças e de entrada cada cofrade de los que } \\
\text { se quisieren entrar en esta santa confradia } \\
\text { pague tres rreales de castilla e las biudas e } \\
\text { mugeres a rreal de castilla y de cada año en } \\
\text { consiguiente su capellania a rreal de plata. }\end{array}$ \\
\hline $\begin{array}{l}\text { DE LOS QUE NO QUISIEREN } \\
\text { SERVIR. } \\
\text { Otrosi ordenamos que todas las perso- } \\
\text { nas elegidas y nombradas por nuestros her- } \\
\text { manos por offiçiales asi Rector como mayor- } \\
\text { domos sean obligados de servir e cumplir } \\
\text { estos tales offiçios que asy nos fueren encar- } \\
\text { gados so pena de quatro libras de çera y ex- } \\
\text { pelidos de nuestra hermanidad e confradia. } \\
\text { Asimismo que las personas a quienes se enco- } \\
\text { mendare la demanda de la limosna que es } \\
\text { tanto neçesaria sean obligados a pedir la di- } \\
\text { cha limosna con que el travajo se comparta so } \\
\text { pena de pidir dos dias por uno o pagar dos } \\
\text { rreales que se pudieran coger. }\end{array}$ & $\begin{array}{l}\text { Yten hordenamos que todas las perso- } \\
\text { nas elexidas e nonbradas por confrades de } \\
\text { la dicha confradia y por ofiçiales para el ser- } \\
\text { viçio della sean obligados de servir e con- } \\
\text { plir los ofiçios en que fueren nonbrados e } \\
\text { encargados so pena de pagar cada uno qua- } \\
\text { tro libras de çera e ser espelidos de la di- } \\
\text { cha confradia para quien se encomendare la } \\
\text { limosna para que la pida sea obligado de la } \\
\text { pedir so la dicha pena. }\end{array}$ \\
\hline
\end{tabular}

Hispania Sacra, LXI

124, julio-diciembre 2009, 447-482, ISSN: 0018-215-X 
La conclusión que se puede obtener de todo ello es la siguiente: es muy probable que las ordenanzas de la Santa Vera Cruz de Vitoria pudieran haber servido como modelo de referencia para la confección de las ordenanzas de la Vera Cruz de Bilbao. De todas formas existen capítulos específicos de cada una de ellas, como es el caso de la obligación de asistir al enterramiento de los ajusticiados en la ciudad de Vitoria, si así lo hubieran requerido estos últimos, se celebran algunas festividades o fechas no siempre coincidentes (todos los viernes del año, las fiestas de Nuestra Señora y las Pascuas en Bilbao, mientras que en Vitoria fueron el día de San Vicente mártir y el día de la Concepción de Nuestra Señora en Vitoria, además del 3 de mayo, día de la invención de la Santa Cruz y el 14 de septiembre, día de la exaltación de la Cruz, fechas no recogidas en el caso bilbaíno) o se desarrollan de forma substancialmente diferente las características de las procesiones de Semana Santa, siendo los ritos procesionales de Vitoria mucho menos espectaculares que en Bilbao, como puede apreciarse en el cuadro que a continuación se adjunta, lo que recuerda, por ejemplo, la afamada Semana Santa de la villa de Valmaseda.

\section{Características de las procesiones organizadas por las cofradías de la Santa Vera Cruz de Vitoria (1538) y Bilbao (1554)}

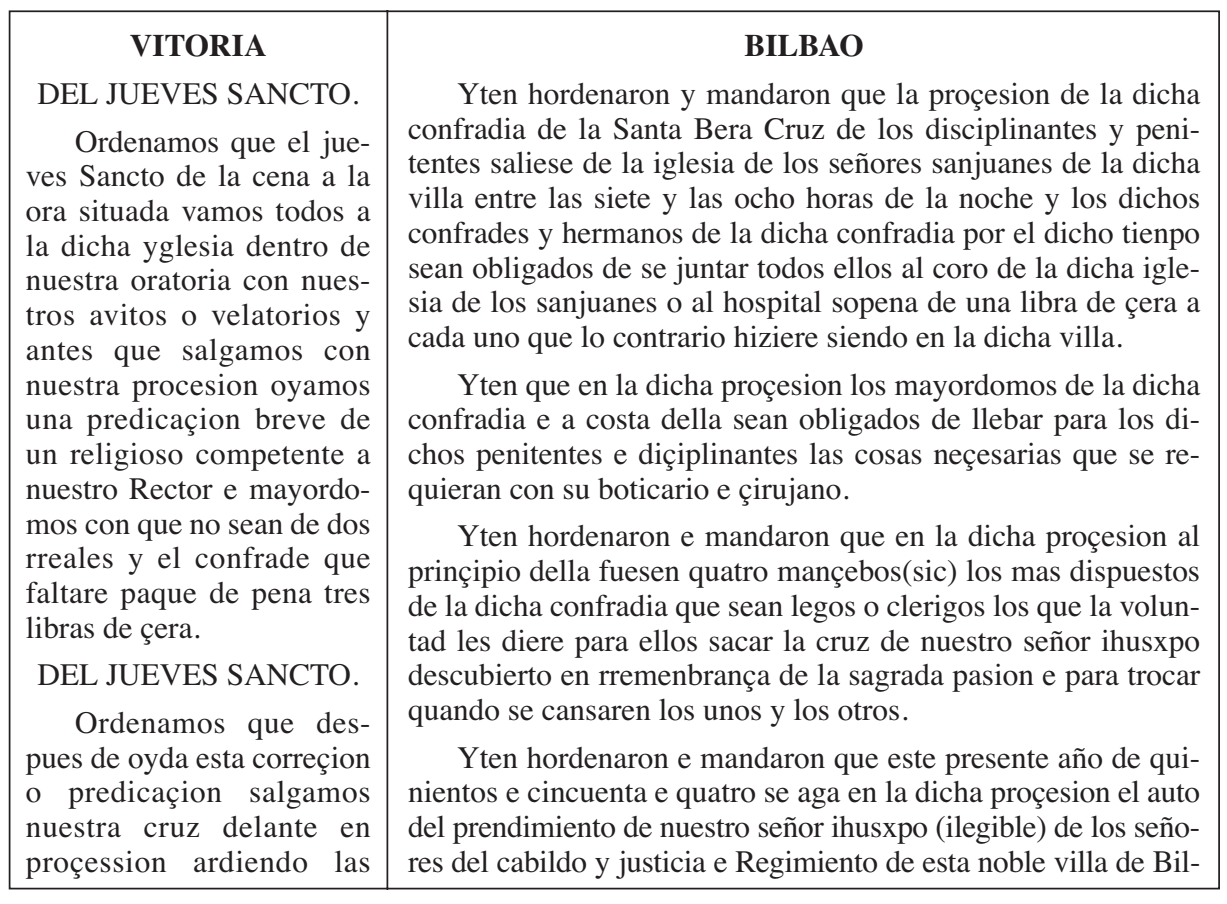


quatro achas las quales lleven niños en vozces altes dixendo en remenbrança de la sagrada pasion de nuestro sennor rredemptor Jesu Xripto desnudos descalços y las espaldas descubiertas en disciplina por los lugares acostumbrados.

\section{DEL JUEVES SANCTO.}

Ordenamos que nuestro Rrector y mayordomos tengan el rrecado neçessario del fuego y lavatorio para los hermanos que el jueves sancto vinieren con neçesidad del tal fuego y lavatorio y que a todos despues de venidos les den colaçion de bino y fructa juntamente con los eclesiasticos hermanos.

\section{DEL RRECTOR COMO HA DE IR A LA PROÇESION.}

Ordenamos que nuestro Rector e maiordomos vayan en la proçesion con sendas baras en las manos desocupando el camino por donde ha de yr la proçesion. bao e después del prendimiento a la çaguera de la dicha proçesion baya el ihusxripto que el dicho cabildo escogiere con la cruz de madera que los dichos mayordomos ternan echo y estara en la dicha iglesia, a cuestas ajudandole Simon Cirineo como le llebaban a Ihesuxripto al tiempo que los judios le llebaron a cruçificar al monte calvario y han de ir dos pregoneros el uno llebandole a xpo con una soga desparço del cuello y el otro tañendo una corneta e pregonando la sentencia que dio Pilatos.

Yten para ello los dichos mayordomos sean obligados de comunicar primeramente con el regimiento de la dicha villa e despues con el cabildo della para que todo baya dirigido en serbiçio de dios e de nuestra señora e para ello el dicho cabildo por el trabajo que ha de rrecebir en la dicha proçesion se le de mill quinientos maravedis e con esto sean obligados hazer lo que la dicha villa e mayordomos de la dicha santa confradia ajuntamente con ellos hordenaren y mandaren.

Yten que para alumbrar a los penitentes e diçiplinantes los que no quisieren disciplina a su voluntad sean obligados tubiendole o podiendolo hazer con su acha de çera encarnada o de otra color para que baya alumbrando e serbiendo en la dicha proçesion e no le teniendo que los dichos mayordomos a costa de la dicha confradia se lo den e después de acabada la dicha proçesion lo torne a los dichos mayordomos.

Yten hordenamos que la dicha proçesion de la dicha iglesia de los San Juanes fuese derechamente sin entrar en otra yglesia por la plaça abajo a entrar en la calle de la tenderia y dende a la yglesia matriz del señor santiago de esta noble villa de Bilbao y echa la oraçion e la perrogativa al santisimo sacramento saliese por la puerta principal de la plaçuela e dende fuese por los caminos nuebos al arenal y entrar en la yglesia del señor san nicolas e dende por la calle abajo baya a entrar en la yglesia del señor son Antón e despues de ay a la dicha yglesia de los señores sanjuanes en donde salio e para ello el dicho cabildo aga todo aquello que en la dicha proçesion es neçesario de hazer e se le pague al dicho cabildo por su trabajo que ha de rreçebir en la proçesion por los dichos mayordomos quatro ducados de oro con que benga el dicho cabildo a hazer todo lo necesario.

Yten los quatro mayordomos e los oficiales de la santa confradia an de ir en medio de la dicha proçesion con su cruz e ynsiña de la dicha confradia rehuyendo e gobernando a los penitentes e confrades della.

Yten que los dichos mayordomos sean obligados de tener el recado necesario de fuego e labatorio para el juebes santo para que despues de benidos sean tratados los que quisieren por manos del boticario e cirujano que para ello por los dichos mayordomos fueren nombrados.

Hispania Sacra, LXI

124, julio-diciembre 2009, 447-482, ISSN: 0018-215-X 
En cualquier caso el contenido de los estatutos de las cofradías de la Vera Cruz de Vitoria, Bilbao y de otras localidades del País Vasco, como no podía ser de otra manera, participa plenamente de la mayoría de los elementos típicos de este tipo de asociaciones concebidas con fines específicamente religiosos:

- Cristo y la Cruz son la referencia central en torno a los que gira su razón de ser y su existencia.

- Jueves Santo, es el día más significativo de la cofradía, fecha en que los cofrades son los protagonistas de una manifestación pública que se irradia hacia el conjunto de la comunidad de cristianos.

- Se hace distinción entre aquellos cofrades que el día de Jueves Santo se flagelan en la procesión y quienes tan sólo llevan la luz ${ }^{52}$.

- Los días de la Invención de la Cruz -3 de mayo- y de la Exaltación de la Cruz -14 de septiembre-, son, conjuntamente con otras festividades particulares de cada una de las cofradías, fechas de especial veneración y relevancia para los cofrades.

\section{CONCLUSIONES}

A tenor de los aspectos considerados en este trabajo de investigación se podría concluir afirmando que las cofradías vascas de la Vera Cruz, correspondientes al siglo XVI, se caracterizaron por disponer de unos patrones estatutarios bastante similares, en sus directrices básicas, al resto de las hermandades hispanas de su misma advocación, por su contenido penitencial -al practicar la disciplina de forma pública-, por la búsqueda de unos beneficios espirituales a cambio de las mortificaciones padecidas de forma individualizada -de este modo se hacen méritos para la obtención de indulgencias y pensando, sobre todo, en la futura salvación del alma del penitente- (las sesiones del concilio de Trento celebradas en 1547 revalorizaron dichos comportamientos) y por su apuesta por potenciar la piedad popular mediante la exaltación de la devoción a la pasión de Jesucristo durante la Semana Santa, de una manera realista y ejemplarizante, lo que se aprecia igualmente en la plástica de las imágenes de los Cristos crucificados, cuyo dolor y sufrimiento no se oculta a los fieles cristianos.

Hoy en día, la continuidad de estas cofradías obviamente está directamente relacionada con motivaciones religiosas, pero la conservación de esta tradición

\footnotetext{
${ }^{52}$ La cofradía de la Santísima Vera Cruz de Navarrete (Álava) de 1597 exigía a los cofrades que llevaran los cirios a la procesión de Jueves de la cena del Señor para alumbrar a los disciplinantes, así como a las misas que la cofradía celebrara a lo largo del año. A cambio la cofradía les enterraría como hermanos.
} 
debe mucho a la capacidad que han tenido para regenerarse determinadas cofradías de la Vera Cruz y al hecho de haberse popularizado como un fenómeno socio-cultural de primer orden valorado por la Iglesia Católica y por los poderes locales y provinciales, no sólo por motivos religiosos, sino igualmente por otros de tipo turístico, como se aprecia a través de la inclusión de este tipo de actos y conmemoraciones rituales religiosos en las guías turísticas locales y provinciales, así como en ese gran instrumento mediático en que se ha convertido Internet.

En la actualidad tan sólo algunas cofradías de la Vera Cruz han logrado o querido conservar las características y rasgos disciplinantes más espectaculares de las viejas organizaciones fundadas en el siglo XVI. Éste es el caso de la cofradía de la Vera Cruz de San Vicente de la Sonsierra en La Rioja, cuyas prácticas flagelantes han provocado el sugerente libro de Patrick Vandermeersch ${ }^{53}$, comunes, por otro lado, en todas estas hermandades en el curso de la Edad Moderna, aunque luego han ido circunscribiendo su actividad a una devoción estricta relacionada con la organización del traslado de los típicos pasos de Semana Santa. No hay duda que, en el caso de San Vicente de la Sonsierra, las solidaridades interpersonales, así como las relaciones de amistad establecidas entre los miembros de la cofradía en el curso de los siglos han llegado a ser tan fuertes y tan sólidas que han vencido o pasado por encima de la desidia, la dejadez o de los nuevos aires de religiosidad que empujaron a las demás cofradías de la Vera Cruz a una relajación o suavización de las precedentes prácticas disciplinantes. Conviene recordar asimismo que en bastantes casos los responsables de las representaciones religiosas de Semana Santa no fueron las cofradías de la Vera Cruz (Orduña -la cofradía «Escuela de Cristo» fundada en 1676 y relacionada con las órdenes mendicantes-, Valmaseda, Segura, etc.), sino que aquéllas están organizadas por otros colectivos laicos y eclesiásticos.

En cualquier caso la notoriedad de las cofradías de la Vera Cruz y sus ejemplificaciones disciplinantes practicadas en las poblaciones donde se fundaron superaron los intereses de los propios cofrades para irradiar sus manifestaciones religiosas al conjunto de los vecinos de la localidad. De este modo durante los días de Semana Santa, más en concreto el día de Jueves Santo, los centros de población que contaron con estas organizaciones confraternales adquirieron una nueva imagen -aunque ésta fuera coyuntural y transitoria-, renovada anualmente y muy distinta de la realidad socio-religiosa existente en el resto del año. Aquellas villas y aldeas del País Vasco que han preservado y conservado las cofradías de la Vera Cruz parecen haberse resistido a perder una parte de sus viejas identidades tradicionales religiosas, aunque éstas no tengan unos orígenes más allá del siglo XVI. La existencia de las cofradías de la Vera Cruz y la conti-

\footnotetext{
${ }^{53}$ Patrick VANDERMEersch, Carne de la pasión: flagelantes y disciplinantes. Contexto históricopsicológico, Madrid, 2004.

Hispania Sacra, LXI

124, julio-diciembre 2009, 447-482, ISSN: 0018-215-X
} 
nuidad de sus representaciones son también, en consecuencia, una toma de conciencia confraternal y vecinal renovada anualmente, de manera particularizada por las fechas de Semana Santa, así como una forma más de hacer sociedad y de integrar a todos o a la mayor parte de los vecinos en un imaginario colectivo común de carácter cristiano, mediante la realización de una serie de ritos y representaciones, cuya simbología trasciende, sin embargo, en el pasado y en el presente el marco estrictamente eclesiástico y religioso, para inmiscuirse o interconectarse con otros de índole antropológica, sociológica, psicológica o cultural.

\section{APÉNDICE DOCUMENTAL}

Ordenanzas de la cofradía de la Vera Cruz de Vitoria.

Archivo Municipal de Vitoria, cajón C, número 26, 3/9/39.

Hordenanzas de la cofradía de la Santissima Vera Cruz desta Ciudad año de 1538 .

En la noble e leal ciudad de Vitoria y arriva en las cassas y camara del ayuntamiento de la dicha ciudad a veynte e tres dias del mes de septiembre y anno del nacimiento de nuestro sennor salvador Jesuxripto de mill e quinientos e treinta e ocho años y estando ende juntos en su ayuntamiento los nobles sennores licenciado Pero Lopez de Ochandiano, alcalde ordinario en la dicha ciudad e tierra y juridicion e sennorios e Joan Ximenez de Adulça e Martin Martinez de Adulça regidores e Joan Martinez de Çuaçu, procurador General y el doctor Ortiz Augoado e Joan Martinez del Castillo e Francisco Diaz de Esquibel e Francisco Veles de Esquibel diputados del ayuntamiento de la dicha dicha ciudad e Joan de Guevara vezino del lugar de Oreytua e Estivaliz de Landa vezino del lugar de Castillo diputados de los hijosdalgo de la juridicion de la dicha çiudad y en presencia e por testimonio de mi Xristoval de Aldana y escrivano fiel del dicho ayuntamiento.

En este ayuntamiento e ante los dichos sennores paresçieron presentes Damian de Mendiola, voticario e Joan de Valmaseda, sastre, vecinos de la dicha ciudad en nombre e como maiordomos de la Sancta Confradia de Vera Cruz de los disciplinantes que esta situada en la iglesia parrochial de de Sennor San Vicente de la dicha ciudad e mostraron e presentaron / una petiçion e juntamente con ella unas ordenanças escriptas en pergamino de cuero segun por ellas pareçia e paresçe su tenor de las quales una en pos de otra son como siguen.

Muy nobles sennores los confrades de la Sancta Vera Cruz besan las manos de $\mathrm{V}$. mercedes y suplican a V. mercedes que para mas rrevalidaçion de su hermandad vean estos capitulos e ordenanças dadas a la dicha confradia por los 
predeçessores de V. merçedes e ansi vistas las manden confirmar por lo qual haran serviçio a nuestro sennor e a nosotros mucho bien e merçed.

En el nombre de Dios omnipotente, Padre, Hijo y Spiritu Sancto, tres personas e un solo Dios verdadero en quien tenemos todo nuestro bien y esperança. Arrimandonos al arbol salutifero de la Cruz en el qual obro nuestro reparador la rredempçion humana tomandola por nuestro amparo y defension hasta el final de nuestra muerte contra las tentaçiones ocasionales e peligros de este mundo para lo qual los confrades y hermanos disciplinantes de la sancta Vera Cruz de la insigne ciudad de Vitoria para que menos indignamente seamos por ella amparados ynterviniendo la gloriossissima Virgen Maria nuestra sennora y el bienaventurado ynbencible martir San Vicente con toda la Corte celestial hazemos las siguientes ordenanças:

DE LA CAPILLA.

Primero ordenamos que la ynvocacion de nuestra devocion y hermandad sea en la yglesia parrochial de señor San Viçente en la capilla de la Vera Cruz donde al presente esta o en otra capilla mas deçente para el serviçio de Dios e voluntad de los dichos hermanos.

\section{DE LA INVENCION.}

Ytem ordenamos que la fiesta de la ynvencion de la sagrada Cruz que es a tres de mayo celebremos en ela dicha capilla la qual nuestro rector e mayordomos hagan endreçar en que ardan dos velas y la lampara a la continua y todos estemos al officio de las visperas e otro dia a la missa e proçesion en la qual hande nuestro crucifixo delante alumbrandolo con las quatro achas de cera y cada confrade con su vela todo de cera verde y el confrade que no se hallare presente hallandose en el pueblo y sano de su perssona pague de penna un quarteron de cera.

\section{DE LA EXALTAÇION.}

Otrosi ordenamos que la fiesta de la exaltaçion de la sagrada cruz que es a catorze de septiembre celebremos en la dicha capilla como la de la ynvençion / de mayo asi a las visperas como a la missa y proçesion con la misma solemnidad y cera so la misma pena.

\section{DEL DIA DE SAN VIÇENTE.}

Ytem ordenamos que en la fiesta de Sennor San Viçente martir nos hallemos presentes a las visperas y missa y proçesion de la manera dicha so la misma pena.

\section{DE LA CONCEPÇION.}

Y otrosi ordenamos que el dia de la fiesta de la concepçion de nuestra Señora en la dicha capilla a visperas y a missa y a la proçesion con la cera e solemnidad arriva dicha so la misma pena. 


\section{DEL RRECTOR Y MAIORDOMOS Y MUNIDOR.}

Ytem ordenamos que aya en esta nuestra hermandad un rrector e tres maiordomos e un munidor al qual munidor den por su travajo de hazer saver lo neçessario a la confradia una loba y una omanpas de sayo de paño verde escuro de dos en dos annos con las ynsignias de la sagrada cruz y en dineros lo que bien visto fueren al rrector e maiordomos e que sea tenido por confrade el tal munidor.

\section{DE LA ÇERA.}

Ordenamos que en esta nuestra hermandad ayan y tengan nuestro rrector e mayordomos quatro achas y dos çiriales que sirvan solo los dos çiriales para sepultar los hijos de nuestros hermanos confrades y tengan tantas velas quantos confrades somos (.........) de çera vend......./

\section{DE LAS MISAS DE LOS MESES.}

Ordenamos que nuestro Rector e maiordomos fagan dezir en la dicha capilla todos los domingos primeros del mes del anno una missa en nombre y comemoraçion de la sagrada Cruz e hande el munidor haziendolo saver a todos los confrades los savados a la tarde y vengan so la pena arriva dicha.

\section{DEL DOMINGO DE RAMOS.}

Ordenamos que todos los hermanos confrades sean congregados juntos el domingo de rramos despues de medio dia siendo llamados por nuestro munidor en nuestro oratorio y ay sean exortados e rrogados se confiessen y comulguen dentro del jueves sancto de la çena e traxa cada uno dellos el jueves Sancto su çedula de como es confesado o haga una solemnidad de como es confesado porque consiga y gane la indulgencia plenaria conçedida de los Summos Pontifices a los hermanos de esta confradia e asimismo sean prevenidos vengan el jueves de la çena del señor con sus aparexos de tunica y de disciplinas a ora limitada por las hermanos presentes so pena de una libra de çera cada uno que no se confessare o hiziere la dicha solenidad.

\section{DEL JUEVES SANCTO.}

Ordenamos que el jueves Sancto de la cena a la ora situada vamos todos a la dicha yglesia dentro de nuestra oratoria con nuestros avitos o velatorios y ants / que salgamos con nuestra procesion oyamos una predicaçion breve de un religioso competente a nuestro Rector e mayordomos con que no sean de dos rreales y el confrade que faltare paque de pena tres libras de çera.

\section{DEL JUEVES SANCTO.}

Ordenamos que despues de oyda esta correçion o predicaçion salganos nuestra cruz delante en proçession ardiendo las quatro achas las quales lleven niños en vozces altes dixendo en remenbrança de la sagrada pasion de nuestro 
sennor rredemptor Jesu Xripto desnudos descalços y las espaldas descubiertas en disciplina por los lugares acostumbrados.

\section{DEL JUEVES SANCTO.}

Ordenamos que nuestro Rrector y mayordomos tengan el rrecado neçessario del fuego y lavatorio para los hermanos que el jueves sancto vinieren con neçesidad del tal fuego y lavatorio y que a todos despues de venidos les den colaçion de bino y fructa juntamente con los eclesiasticos hermanos.

\section{DE JUEVES SANCTO.}

Ordenamos que en la noche de jueves Sancto o otro dia de / congregaçion de los hermanos si por caso alguno mal mirando el serviçio de Dios y no veniendo con el acatamiento devido pusiere algun escandalo o rruido o se desmandare de palabra o de obra contra otro alguno pague de pena dos libras de çera.

\section{DE LOS ESIMIDOS.}

Ordenamos que los confrades y hermanos que fueren de sesenta annos arriva y todos los que se hallaren enfermos en este tiempo e los ausentes del pueblo y las mugeres biduas que fueren de nuestros hermanos no sean obligados a esto de esta proçesion con que los tales hermanos de sesenta annos arriva vengan a la dicha proçesion con su avito.

\section{DEL RRECTOR COMO HA DE IR A LA PROÇESION.}

Ordenamos que nuestro Rector e maiordomos vayan en la proçesion con sendas baras en las manos desocupando el camino por donde ha de yr la proçesion.

\section{DE LOS FINADOS.}

Ordenamos que quando algun confrade o muger del tal muriere lo vamos a onrrar con las quatro achas y velas neçesarias so pena de tres maravedis y se diga por el tal finado o finada el dia del enterrorio o otros dias siguientes una missa cantada de rrequien con sus rresponsos en la dicha capilla / o en el ospital de la plaça por rraçon de las graçias otorgadas al ospital y todos estemos presentes y lo hagan saver nuestros mayordomos en caso del tal difunto.

\section{DE LOS ESTRANJEROS.}

Otrossi ordenamos que si por casso alguna persona con devoçion se encomendare a la ora de su muerte a la dicha hermanidad y rogase la resçivan por confrade sea rreçivido por confrade y le llieven toda la çera e vamos todos a la sepultura so la pena arriva dicha e se le diga su missa de rrequien e rresponso con que de e pague un castellano de oro para las costas de la missa e cera que en sus obsequias se gastaren y si fuere pobre vamos todos con las quatro achas solamente a lo sepultar. 


\section{DE LOS JUSTIÇIADOS.}

E ordenamos asimismo si algun pobre sentençiado a muerte por justicia en esta ciudad se encomendare a la dicha hermanidad lleven las dichas quatro achas de çera e haga saver el munidor vamos todos a lo sepultar so pena de tres maravedis.

\section{DEL RRESÇIVIR CONFRADES.}

Ordenamos que nuestro Rector e mayordomos no resçivan en esta nuestra hermanidad ningun confrade sin lo hazer saver a todos los hermanos porque primero sepan del tal que ha de ser resçivido si condesçendera con la obra e voluntad y condiçion en todo aquesto que se contiene en estas / nuestras ordenanças y que el tal asi rresçivido pague de entrada tres rreales y si es hijo de confrade Real y medio.

\section{DEL NOMBRAR OFFIÇIALES.}

Otrosi ordenamos que otro dia siguiente de la ynvençion de la sagrada Cruz que es a tres de mayo digan en la dicha capilla una misa de rrequien cantada y un responso en memoria de los finados nuestros hermanos a las siete oras e nos hallemos todos presentes con nuestras velas y proçesion so pena de un quarteron de çera y la misa dicha entremos en nuestro oratorio y ay nombraremos Rector y mayordomos nuevos e otras dos personas acompannadas con nuestro Rrector para que rresçivan cuenta y rraçon del rrector e mayordomos pasados del cargo e del cargo e pena y limosnas e de todo lo anexo en la confradia.

DEL ALCANCE.

Ordenamos que si algo se hiziera de alcançe al rrector e mayordomos passados se les de y entregue a los nuevos esleidos luego este dia con mayor del ? acuerdo de la confradia.

\section{DE LO QUE SE DA AL CORO.}

Ordenamos que al sennor cura y coro de la dicha yglesia se les de por cada missa cantada con diacono y subdiacono un rreal e por las otras a medio real. /

\section{DE LOS QUE NO QUISIEREN SERVIR.}

Otrosi ordenamos que todas las personas elegidas y nombradas por nuestros hermanos por offiçiales asi Rector como mayordomos sean obligados de servir e cumplir estos tales offiçios que asy nos fueren encargados so pean de quatro libras de çera y expelidos de nuestra hermanidad e confradia. Asimismo que las personas a quienes se encomendare la demanda de la limosna que es tanto neçesaria sean obligados a pedir la dicha limosna con que el travajo se comparta so pena de pidir dos dias por uno o pagar dos rreales que se pudieran coger. 


\section{DE LOS QUE NO QUISIEREN SER.}

Ordenamos que qualquiera hermano nuestro no quiriendose someter a estas nuestras ordenanças e poner por obra lo que en ellas se contiene e quiera salir de esta nuestra hermanidad pague de pena tres reales e sea vorrado del libro en numero.

\section{DE LA MANERA EN EL HABLAR.}

Ordenamos que los hermanos confrades hallandonos juntos en nuestro oratorio o capitulo ninguno de nosotros hable ni proponga platica ninguna a menos que el otro calle y tome primero la bara en la mano so pena de tres maravedis.

\section{DEL LIBRO MANUAL.}

Ordenamos que nuestro Rector e mayordomos tengan juntamente con lo arriva dicho cera y todo lo que es de la confradia por ynventario e un libro en que se escriva el cargo y descargo e penas y mas un manual en que escrivan las limosnas que se cogen y las firmas los que las cogieren.

$\mathrm{Y}$ asi traida y presentada la dicha petiçion de ordenanças por los dichos Damian de Mendiola e Joan de Valmaseda que de suso van emcorporadas ante los dichos sennores justiçia, regimiento e leidos de mi el dicho escrivano la dicha petiçion luego los dichos Damian de Mendiola e Joan de Valmaseda dixieron que ellos en nombre de la dicha confradia y confrades dellas sus partes asi lo pidian y suplicavan como en la dicha petiçion se dezia. E luego los dichos sennores dixieron que oyan y encargavan al doctor Ortis avogado que presente estava vea las dichas ordenanças e vistas haga relaçion dellas en el primer ayuntamiento. En la noble e leal ciudad de Vitoria arriva en las cassa y camara del / ayuntamiento de la dicha ciudad a veinte y çinco dias del mes de septiembre e anno del naçimiento de nuestro Sennor Salvador Jesu Xripto de mill y quinientos e treinta e ocho annos. 